\title{
Bilsem Denetim Rehberinin Yasal Belgeler ve Alanyazın Temelinde incelenmesi
}

\author{
Doç. Dr. Yılmaz TONBUL \\ Ege Üniversitesi-Türkiye \\ yilmaztonbul@gmail.com
}

\author{
Figen ATA ÇiĞDEM \\ Milli Ĕgitim Bakanlığı \\ atafigen@gmail.com
}

\begin{abstract}
Özet:
Bu araştırmanın amacı, Teftiş Kurulu Başkanlığı tarafından yayınlanan Bilim ve Sanat Merkezleri denetim rehberinin, yurt içi alanyazın ve yasal belgeler temelinde incelenerek tutarsızlıkların saptanması ve bu doğrultuda uygulayıcılara ve araştırmacılara önerilerin geliştirilmesidir. Çalışmada nitel araştırma desenlerinden doküman incelemesi kullanılmış, veriler içerik analiziyle çözümlenmiştir. Çalışmada, BILSEM denetim rehberinin yasal belgelerle tutarllık teması kapsaminda, BILSEM denetim rehberinin yasal belgelere tutarsılık oranı \%69 olarak bulunmuştur. Yasal belgelerle en fazla tutarsızlık, yasal dayanak belirsizliği, yasal belgelere göre güncel olmama ve yasal dayanağa göre fazla ifadelendirilmesi kodlarında bulunmuştur. BILSEM denetim rehberinin alanyazınla genel olarak tutarllığa sahip olduğu ve denetim bilimine ilişkin üretilen bilgilerin rehberde yer aldığı görülmüştür. Bununla birlikte denetim ilkelerinde alanyazınla aykırı durumlar ve denetim ilkelerinin ifade ediliş biçimi açısından kavram tutarsızlığı, denetim rehberinin bazı bölümlerinde bilimsel çalışmalara yeterince atıf yapmama, alanyazında olan ancak denetim rehberinde olmayan ifadelerde içerik eksikliği kategorilerinde eksikler saptanmıştır. Bulgular, ilişkili kuramlarla ve alanyazın sonuçları ile desteklenerek yorumlanmış ve öneriler geliştirilmiştir.
\end{abstract}

Keywords: Denetim Rehberi, BILSEM, Denetmen

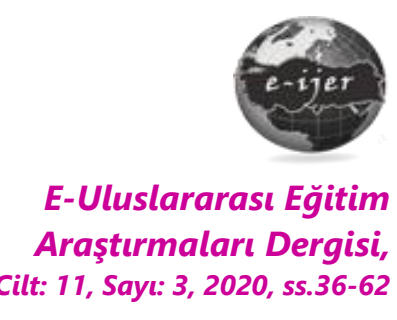

DOI: 10.19160/ijer.804118

\section{Önerilen Atıf}

Tonbul, Y. \&. Ata Çiğdem, F. (2020). Bilsem Denetim Rehberinin Yasal Belgeler ve Alanyazın Temelinde İncelenmesi, E-International Journal of Educational Research, Vol: 11, No: 3, 2020, pp. 36-62, DOI: 10.19160/ijer.804118 


\section{GiRiş}

Denetim anlayışı ilk başlarda eksikliklerin tespit edilme süreci, öğretmene doğru yolu gösterme gibi daha çok davranış kontrolü şeklinde tanımlanmıştır. Bursalıoğlu (2010), denetimi kamu adına davranışı kontrol etme süreci olarak tanımlamaktadır. Aydın (2014), ise denetimi örgütsel eylemlerin kabul edilen amaçlar doğrultusunda önceden belirlenen ilke ve kurallara uygun olup olmadığının anlaşılması süreci şeklinde ifade etmiştir. Eğitimin yönetimi ve denetimi, eğitim bilimleri içinde birer alt bilim dalı olarak tanımlanmaktadır (Toprakçı ve Kadı, 2014). Eğitim yönetimi, eğitim alanında bir amaca ulaşmak için bir araya gelen en az iki insanın katkılarının amaca yönlendirilmesi sürecini inceleyen, açıklayan ve bu süreci öndeyileyen bilim dalıdır (Toprakçı, 2008). Eğitim denetimi, eğitimde gerçekleştirilen eylemlerin; mevcut yasal işleyişe, belirlenen amaca, hazırlanan plana, eldeki madde ve insan kaynaklarına uygun olup olmadığını kontrol etme sürecidir (Toprakçı, Çakırer, Bilbay, Bagcivan ve Bayraktutan, 2010: 15). Denetim amacına bakıldığına, denetimin karakterini şekillendiren iki farklı yönelim olarak kendini gösterir. Biri yasal dayanaklara, mevzuata uygunluk ve belirlenen amaçlara erişmeye yönelik faaliyetlerin değerlendirilmesi olarak denetim; diğeri ise eğitim süreçlerinin iyileştirilmesine yönelik rehberlik olarak denetimdir (Lillis, 1992: 8). Devlette yer alan tüm kurumların belirlenen hedefleri ne kadar gerçekleştirdikleri, aksayan yönlerin ne olduğu, söz konusu aksamaların nedenlerini ortaya koyarak kurumlarda düzenlemelere gidilmesi, tüm sektörler için önem arz ettiği görülmektedir. Gerek özel sektörde gerekse kamusal alanda performans raporları, akreditasyon uygulamaları, Toplam Kalite Yönetimi çerçevesinde yapılan uygulamaların 'işlerin yolunda gidip gitmediğini' anlamak ve gerekli müdahaleleri yapmak amacıyla gerçekleştirildiği söylenebilir. Kurumların ve devletin sürekliliğinde işlevsel bir denetim mekanizmasının gerekli hatta zorunlu olduğu görülmektedir. Bu zorunluluk eğitim kurumları için de geçerlidir ve bundan dolayı eğitim kurumlarında denetim sürekliliği için konunun yasal düzenlemelerle açık biçimde denetimin çerçevesinin çizildiği görülmektedir.

Denetimin amacına ulaşmasında, teftiş faaliyetlerinin sürekliliği, her kademe için ayrı yapılandırılması, her branş için dahi farklı değerlendirme formlarının kullanılması ile ilgili (Tonbul ve Baysülen, 2017) alanyazında araştırma bulguları bulunmaktadır. Eğitim denetiminde sürekliliğin sağlanmasının yanı sıra denetim her düzey ve her kademe için yapılandırılması, önemli olduğuna dair görüşlere alanyazında sıklıkla rastlanmaktadır. Eğitim ve öğretim, Anayasa'nın 42. maddesine göre Devletin gözetimi ve denetimi altında, Atatürk ilke ve inkılâpları doğrultusunda, çağdaş esaslara göre gerçekleştirilir. 1739 sayılı Milli Eğitim Temel Kanunu'nun 56. maddesine göre, eğitim-öğretim hizmetinin devlet adına yürütülmesinden, gözetim ve denetiminden Milli Eğitim Bakanlığı (MEB) sorumludur (MEB, 1973). Milli Eğitim Bakanlığı teşkilat yapısı içerisinde yer alan Teftiş Kurulu Başkanlığı, bakanlık teşkilatında yer alan kurum ve kuruluşlar ile Bakanlığın denetimine tabi kurumlara yönelik denetim, rehberlik, araştırma, inceleme, soruşturma ve ön inceleme işlemlerini yürütmek ile görevlidir (MEB, 2016). Bakanlık tarafından '2014-2017 Rehberlik ve Denetim Programı ile Yıllık Faaliyet Planı ve Hazırlama Rehberi' konulu 24/07/2014 tarih ve 3148976 yazı ve ekleri illere gönderilerek, denetim hizmetlerinin nasıl planlanacağı ve uygulanacağı açıklanmıştır. Ayrıca her okul ve eğitim kurumu türü için ayrı ayrı denetim rehberleri Teftiş Kurulu Başkanlığı tarafından hazırlanmakta ve resmi web sitesinde yayınlanmaktadır (Teftiş Kurulu Başkanlığı, 2020a). Rehberlik ve Denetim Başkanlığı değişen ve gelişen şartlara 
göre sorunları ve çözümünü ortaya koyabilmek, var olan durumu iyileştirmek kamu kaynaklarını daha etkin, verimli ve yerinde kullanmayı ve bunun yanı sıra Maarif Müfettişleri Başkanlıkları arasında uygulama birliği ve standartlaşmayı sağlamayı hedeflemektedir. Günümüzde, denetim anlayışındaki değişme ve gelişmeler denetim standartlarının yeniden incelenmesini zorunlu hale getirmiş, hedeflenen uygulama birliği ve standartlaşmayı sağlamak adına denetim rehberleri hazırlanmıştır (Teftiş Kurulu Başkanlığı, 2020:3-4). Yayınlanan denetim rehberleri incelendiğinde Bilim ve Sanat Merkezleri (BILSEM)'ne ilişkin de bir rehberlik ve denetim rehberinin olduğu görülmektedir. BiLSEM, görsel sanatlar, müzik, genel zihinsel yetenek alanlarında özel yetenekli olduğu belirlenen öğrencilere, yeteneklerini geliştirerek kapasitelerini en üst düzeyde kullanmalarını sağlayabilmek amacıyla destek eğitim hizmeti vermek üzere açılan kurumlardır (Özel Eğitim Hizmetleri Yönetmeliği, 2018). Buradan yola çıkıldığında, yurtiçinde ve yurt dışında özel yetenekli ve üstün zekâlı öğrencilerin eğitimine yönelik çalışmaların olduğu görülmektedir.

Dünyada üstün zekâlı ve yetenekli öğrencilerin eğitim hakları, tanılanmaları ve en iyi şekilde eğitilmeleri ile ilgili çalışmalar yapılmaktadır. Ülkelerde birbirinden farklı uygulamalara rastlanmasına rağmen, bireylere hızlandırma, farklılaştırma ve zenginleştirme yapılarak eğitim verilmesi fikri ortaktır. Bazı ülkelerde üstün zekâlı ve yetenekli bireylerin sınıfa erken başlatılması ve sınıf atlatılması söz konusu olurken bazı ülkelerde zenginleştirilmiş eğitim programları ve ayrı sınıf uygulamaları görülmektedir (Kılıç, 2018:141). Bu alanda en etkili sistemlerden birini kuran ülkeler arasında İsrail gelmektedir (Hızlı, 2014: 53). İsrail'de üstün zekâlılar için programlar 1970'lerde Milli Eğitim Bakanlığı altında kurulmuş bölüm tarafından yönetilmekte ve finanse edilmektedir. İngiltere'de üstün zekâlı çocuklara yönelik eğitim 1944'te başlamıştır. Günümüzde ise üstün zekâlı ve yetenekli öğrencilere İngiltere'nin yaklaşımı eğitim sistemi içerisinde bütünleyicidir (Boettger, 2015: 159; Akt. Kılıç, 2018). İngiltere'de üstün zekâlı ve yetenekli çocukların gidebileceği özel bir okul bulunmamaktadır ama üstün yetenekli çocukların gidebileceği kilise korosu, müzik, bale, tiyatro sanatı okulu gibi okullar vardır (Vainar, Gali ve Shaknina, 2016; Akt. Kılıç, 2018). İsviçre'de ise 2009 yılında beş yıllık bir pilot çalışma olarak ortaokul ikinci kademe öğrencilerine yönelik hükümet girişimiyle gerçekleştirilen üstün yetenekli bireylerin eğitimi programı, üstün yetenekli bireylerin eğitimine yönelik attığı ilk adım sayılabilir(Friel, 2015: 2-4). Bu bilgiler bağlamında, ülkelerde üstün zekâlı öğrencilere yönelik çalışmaların eğitim sistemi ile bütünleyici özellikte olduğu, İngiltere'de her ne kadar üstün zekâlılara yönelik eğitimin Eğitim ve İstihdam Bakanlığı (DFEE) altında kontrol ve denetimi gerçekleştirilse de, bu amaca hizmet eden ayrı bir kurum/ okul oluşturulmadığı görülmektedir. Ancak birçok ülkede bu amaca yönelik kurumların da var olduğu bilinmektedir. Örneğin Birleşik Kralıktaki dünyanın dört bir yanından lise öğrencilerine (13-18 yaş) öğrenme ve yaratıcı zenginleştirme hizmeti sunan Exclusive Summer School (Özel Yaz Okulu); Almanya'daki Felsefe, sinirbilim, psikoloji, bilgisayar bilimi ve tıp alanlarını bütünleştiren hafıza ve zihin üzerine disiplinler arası dersler veren European Summer School (Avrupa Yaz Okulu); Afrika'nın yetenekli çocuklarına tam potansiyellerini geliştirme fırsatı sunan, Afrika ve İngiltere yöneticileri ve eğitim uzmanları tarafından yönetilen ve benzersiz bir eğitim deneyimi sunmak için matematik ve bilgisayar uzmanlığı ile dünya standartlarında hizmet sunan African Gifted Foundation (Afrika Üstün Zekalı Vakfı); Hırvatistan'daki eğitim sisteminde üstün yetenekli öğrenciler ve haklar" konulu İnsan Hakları Günü ile birlikte yetenekli topluluk içinde ve onların ihtiyaçlarında farkındalığı arttırmak için 
yuvarlak masa toplantıları ve halka açık gösteriler düzenleme amacıyla kurulan Center for Gifted Children, Rijeka (Rijeka Üstün Zekalı Çocuklar Merkezi) ve üstün yetenekli ve yetenekli çocukların büyümesini ve gelişimini eğitim, savunma, topluluk oluşturma ve araştırma yoluyla geliştirenlere destek olma amacıyla kurulan "Association for Gifted Children" (Üstün Zekalı Çocuklar Derneği) bunlar arasında sayılabilir (NAGC, 2019).

Türkiye'de Cumhuriyet döneminde devletin himayesinde üstün yetenekli çocukların eğitilmesi için 1948 yılında çıkarılan İdil Biret- Suna Kan yasası 1956 yılında yasa kapsamı genişletilerek "6660 Sayılı Müzik ve Plastik Sanatlarda Olağanüstü Yetenek Gösteren Çocuklar Hakkında Kanun" yürürlüğe girmiştir. Bu kanun halen yürürlüktedir; fakat 1978'den sonra yasa kapsamına alınmadığı gözlenmiştir (Özsoy, Saldıroğlu ve Sever, 1991). Türkiye'de Bilim ve Sanat Merkezleri kuruluşunun geçmişi 1990'lı yıllara dayanmaktadır. 1995 yılında Milli Eğitim Bakanlığı tarafından kurulan Bilim ve Sanat Merkezleri, anaokulu, ilköğretim ve ortaöğretim kurumlarına devam eden özel yetenekli çocukların devam ettikleri örgün programa ek olarak zenginleştirme eğitimi aldıkları kurumlardır. Bu öğrenciler örgün eğitimleriyle doğru orantılı olarak BILSEM'lerde ilgi ve yeteneklerine göre öğretmenleriyle birlikte çalışmaktadırlar. Böylece kendi okullarında toplumla bütünleşen çocuklar bu merkezler aracılığı ile kendi yetenekleri doğrultusunda gelişmektedirler (Bapoğlu, Gürsoy ve Aral, 2016).

Ülkemizde hizmet veren BILSEM'ler gelecekte bilim ve sanatta ülkemize öncelik edecek bireyleri yetiştirmeyi hedeflemektedir. Bu sebeple bu kurumlardaki yönetim biçimi, örgüt yapısı, hiyerarşik düzen dikkat edilmesi gereken bir unsur olmuştur. Eğitim denetimi süreci aşamaları her kurum gibi BiLSEM için de geçerlidir. Aydın'a (2014: 1820) göre ilk aşama olarak, denetlenecek olanın belirlenmesi gerçekleşir ve denetimin yapılacağı konulara karar verilir. Denetlenecek olan belirlendikten sonra denetim öncesi hazırlık aşamasına geçilir. Bu aşamada denetlenecek olan kişi ya da kurumun faaliyetlerine yönelik bir denetim hazırlığı gerçekleşir. Daha sonra denetimin yapılabilmesi için gereken standartlar oluşturulur. Sonrasında, denetim gerçekleştirilir ve veriler toplanır. Toplanan verilerle daha önce oluşturulan standartlar karşılaştırılır ve verilerin beklenen standartları ne ölçüde karşıladığı ortaya koyulur. Son olarak, raporlaştırma ile elde edilen veriler ve belirlenen standartlar doğrultusunda mevcut durum değerlendirilir. Denetim, ilkeleri, yöntemleri ve kuramsal bir temeli olan bilimsel bir alandır. Bu nedenle, denetlenen ve denetmen arasındaki denetim ilişkisinin bilimsel bir boyutu olmalıdır. Denetmenler de önceden planlanan bu bilimsel verilere göre denetim yaptığı için, denetim esnasında belirli standartlardan başka bir şey aramamaktadır. Bu şekilde gerçekleştirilen bir denetim, bilimsel temelde ve nesnel kurallara göre gerçekleştirilmiş olacaktır (Can ve Gündüz, 2019).

Denetimi düzenleyen yasalar ve BILLSEM ile ilgili alanında yapılan araştırmalara bakıldığında, Yücel ve Toprakçı (2009), öğretmen denetiminin eski ve yeni yasal metinlerinde, içerik ve biçim olarak eğitsel denetimin yer alma düzeyinin değerlendirmiştir. Denetimin yeni yasal metinleri hem biçim hem de içerik olarak eğitsel denetime daha fazla yer vermekte olduğu sonucuna erişmiştir. Keskin, Samancı, Aydın (2013), Kazu ve Şenol (2012), Koç (2016), Güneş (2018), araştırmalarında, BíLSEM kurumlarının fiziki ortam şartları, personel sayılarının yetersizliği, yönetimleri, eğitim öğretim uygulamaları, öğrenci kapasitesi, tanılama süreçleri, öğrenciler, velilerle ilgili konularda sorunlar bulunduğu belirtmektedirler. Alan yazın incelendiğinde; yapılan çalışmaları Bilim ve Sanat Merkezlerinin durumları, yapılandırma ihtiyaçları (Güneş, 
2018), sunulan eğitimin kalitesi ve etkisi, memnuniyet (Summak, Çelik ve Şahin, 2014; Koç, 2016), öğrenci tanılama süreçleri ve eğitim modelleri (Tortop, 2012), Bilim ve Sanat Merkezleri'ne öğretmen ve yönetici seçimi, nitelikleri ve görüşleri (Hızlı, 2014; Keskin, Samancı ve Aydın, 2013; Kazu ve Şenol, 2012; Koç, 2016; Kılıç, 2018; Güneş, 2018; Sak., vd., 2015; Yazgan, 2020), özel yeteneklilere tanınan haklar (Kazu ve Şenol, 2012) şeklinde gruplanmaktadır. Bu bilgiler ışığında, müfettişlerin rehberlik etkinliklerinin niteliğinin önemli olduğu ve kuruma özgü denetim süreçlerinin de farklılık göstermesi gerektiği söylenebilir. İlğan'ın (2008) araştırma bulguları da hem müfettişlerin hem öğretmenlerin farklılaştııılmış denetim modelini benimsediklerini ortaya koymaktadır. Denetim rehberlerinde de bu farklılıkların olması gerektiği düşünülmektedir.

Yukarıda değinilen çalışmalar bağlamında, BILSEM denetimine veya denetim rehberine ilişkin ne alanyazında ne de Teftiş Kurulu Başkanlığı tarafından raporlanan, herhangi bir çalışmaya rastlanmamıştır. BILSEM kurumlarına ilişkin birçok sorun (Keskin, Samancı, Aydın, 2013; Kazu ve Şenol, 2012; Koç, 2016;Güneş, 2018) olduğu yönünde çalışmaların var olmasına karşın, yapılan alanyazın taramasında kurum ve ders denetimine ilişkin doğrudan bir çalışmaya rastlanmamıştır. Öte yandan Şahin'in (2017) araştırma bulguları da son yıllarda denetimin etkisinin azaldığını ortaya koymaktadır. Bu durumun bir çok nedeni olmakla birlikte sonuç itibarıla, kaygı verici olarak değerlendirilmiştir. Yapısal anlamda BILSEM'in tüm işleyişi yasal düzenlemelerle belirlenmektedir. Çalışanlar, belirli yetkinliklere göre (lisansüstü eğitim tamamlama, proje yazma, yayın yapma vb.) seçilmektedir. Örgütsel anlamda BILSEM, Mintzberg beş örgüt yapısından en fazla profesyonel bürokratik yapıya benzerlik gösterdiği, ancak kuruluş amacı dikkate alındığında, esnek veya bölümlenmiş yapı özelliği göstermesi gerektiği söylenebilir (Yazgan, 2020). Dolayısıyla, "kitle eğitimi" anlayışı ile bu kurumlarda uygulamalar yapmak, bu kurumların kuruluş amaç ve felsefeleri örtüşmeyecektir. Bu durum, BILSEM kurumlarında gerçekleştirilecek olan denetimlerin de farklılık göstermesi gerektirdiğini ve denetimde kullanılması için hazırlanan rehberin de bu kapsamda incelenmesinin gerekli olduğu söylenebilir.

Milli Eğitim Bakanlığı Teftiş Kurulu Başkanlığı görev, yetki, sorumluluk ve çalışma esaslarının yer aldığı yönergede (MEB, 2017a) Rehberlik ve Denetim Daire Başkanlığı görevleri kapsamında "Madde 25: g) Bakanlık merkez, taşra ve yurtdışı teşkilatı ile okul, kurum ve personelin rehberlik ve denetimine ilişkin esasların ve rehberlerin hazırlanması, uygulanması ve geliştirilmesine ilişkin iş ve işlemleri yürütmek," ifadesinin yer aldığı görülmekte ve bu doğrultuda da denetim rehberlerinin güncellenmesi gerektiği sonucuna varılmaktadır. Bu durum, müfettişlerin denetim faaliyetlerini gerçekleştirebilmeleri için yayınlanmış olan denetim rehberlerinin, yasal belgeler ve alanyazın ile tutarlılığının belirlenmesinin gerekliliğini ve önemini ortaya koymaktadır. Tonbul (2020) örgütsel işleyişte ortaya çıkan sorunların ilişkili kuramların bilgisinden yararlanarak daha iyi anlaşılabileceğinin ileri sürmektedir. Örneğin Weber'in Bürokrasi Kuramı incelendiğinde, örgütsel işleyişte her faaliyetin açıkça tanımlanmasını, görev, yetki ve sorumluluk dağılımlarının yazılı belgelerle birbiri ile tutarlı olacak şekilde kayıt altına alınması gerektiği, aksi halde karmaşaya yol açacağı vurgusu vardır. Buna göre denetim rehberleri, ilişki ve ilintili olduğu diğer tüm yasal metinlerle uyum içerisinde olması gerekir. Kaos Kuramı karmaşayı doğal saymakla birlikte, alt sistemler arasındaki etkileşim yetersizliğinin belirsizliği daha da artıracağını öne sürmektedir. Kurama göre, kontrol edilebileceklerin oranını artırmanın düzenlemelerle mümkün olacağı varsayılmıştır. Yine Kurumsal Kuramda, örgütsel yapılarda-örneğin BiLSEM'de-kendi 
dinamikleri ile sorunları saptamanın, bunları ilişkili kurumlarla paylaşarak gerekli düzenlemelerin yapılması için gerekli birimlerin oluşturulmasının önemi vurgulanmıştır (Yavuz, 2016). Dinamik Yetenekler Kuramı (Teece, 2007) bir kurumun sürekliliğinin çevresel değişimleri algılama, bunlarla uyumsuzluğu ortaya koyabilme ve yenileşme kapasitesi ile ilişkilendirmektedir. Buna göre kurumlar, kurumların denetiminde işe koşulan rehberler çevresel değişimleri, güncellemeleri, alanyazındaki gelişmeleri izlemek ve bunlara uygun uyarlamaları yapmakla yükümlüdür denilebilir. Bu araştırma denetim rehberinin incelenerek yasal metinlerle ve alanyazınla tutarsızlığının saptanmasının ötesinde, daha sonra yapılacak araştırmalarla işleyiş̧te aksayan yönlere de ışık tutmayı hedeflemektedir. Tüm kurumsal yapılarda olduğu gibi eğitim kurumlarındaki işleyiş de yasal metinlerle uyum içerisinde olmalıdır. Araştırmanın amacı yasal belgeler temelinde BiLSEM denetim rehberinin incelenerek tutarsızlıkların saptanması ve yurt içi alanyazınla tutarsızlıkların ortaya konularak, uygulayıcılara ve araştırmacılara yönelik önerilerin geliştirilmesidir. BILSEM denetim rehberinin incelenmesinin ve sorunların saptanmasının, BILSEM kurumu özelinde denetim sürecinin standartlarının oluşturulmasına da katkı sağlayacağı düşünülmektedir.

\section{YÖNTEM}

Bu bölümde, araştırmanın modeli, verilerin elde edilme süreci, verilerin analizi, geçerlilik ve güvenirlik kısımlarına yer verilmektedir.

\section{Araştırmanın Modeli:}

Araştırmada, Bilim ve Sanat Merkezi Kurumları Rehberlik ve Denetim Rehberi'nin ele alınarak değerlendirilmesi ve öneriler getirilmesi amaçlanmış, bu bağlamda nitel araştırma yöntemi kullanılmıştır. Nitel araştırma, Yıldırım ve Şimşek (2016)'ya göre görüşme, gözlem, doküman analizi gibi nitel veri toplama tekniklerinin kullanıldığı, algı ve durumların kendi doğal ortamlarında gerçekçi ve bütüncül bir yaklaşımla ortaya konmasında nitel süreçlerin izlendiği araştırma türü olarak tanımlanmaktadır. Bu çalışmada nitel araştırma temelinde doküman analizi yöntemi kullanılmıştır. Doküman incelemesi, araştııı ması hedeflenen olay ve olgular hakkında bilgi içeren yazılı materyallerin analizini kapsar (Yıldııım ve Şimşek, 2016). Doküman incelemesi kişisel dokümanlarda olduğu gibi kamu ve arşiv dokümanlarında da kullanılabilir. Denetim rehberleri MEB Teftiş Kurulu Başkanlığı́nın denetimde uygulama birliği sağlamak amacıyla kullandığı kamu belgeleridir ve doküman incelemesine uygun kaynaklar olarak değerlendirilmiştir. Araştırmada, bu belgeler doküman incelemesinin aşamalarına göre analiz edilmiştir.

\section{Çalışma dokümanı:}

MEB Teftiş Kurulu Başkanlığı, 2016 yılında çeşitli kurumların teftişine yönelik olarak hazırlanan 16 adet rehberlik ve denetim rehberi yayımlamıştır. Bu rehberler, maarif müfettişlerinin teftiş sürecinde uygulayacakları esasları içermektedir. Çalışma dokümanı yayımlanan rehberler arasında yer alan Bilim ve Sanat Merkezleri Kurumları Rehberlik ve Denetim Rehberi'dir. Söz konusu belgeye, MEB Teftiş Kurulu Başkanlığı'nın internet sitesinin (http://tkb.meb.gov.tr/www/yayinlarimiz/icerik/13) "Yayınlarımız" sayfasından 24.04.2020 tarihinde ulaşılmıştır. Alanyazınla tutarlıı/ı/tutarsızlık alt amacı 
için taranan ulusal denetim kitapları, son on yıla ait alanyazında yapılmış olan doktora tezleri ve makaleler ile sınırlandırılmıştır. Tezlere ilişkin tarama YÖK veritabanı üzerinden gerçekleştirilirken, makaleler Google Scholar, Ege Üniversitesi erişime açık veri tabanı üzerinden yıl filtrelemesi kullanılarak gerçekleştirilmiştir. Alanyazın ile uyum alt amacı için ortaya çıkan veriler, burada adı geçen yayınlarla ve bu yayınların taranmasında kullanılan kodlarla sınırlıdır.

\section{Verilerin Toplanması ve Analizi:}

Doküman incelemesi tekniğinin uygulama aşamaları, dokümanlara ulaşma, dokümanların orijinalliğini kontrol etme, dokümanları anlama, veriyi analiz etme ve kullanma (Forster, 1995: Akt. Yıldırım ve Şimşek, 2016). Dokümanlara ulaşma aşamasında Bilim ve Sanat Merkezi Kurumları Rehberlik ve Denetim Rehberi'ne MEB Teftiş Kurulu Başkanlığı́nın resmi internet sitesinden; ardından rehberde bahsi geçen ilgili kanun, yönetmelik, yönerge, genelge ve diğer belgelere yine bakanlığın kendi sitesinden ulaşılmıştır ve orijinalliği teyit edilmiştir. Dokümanları anlama aşamasında öncelikle ilgili rehber ardından rehberde bahsi geçen mevzuatlar detaylı olarak incelenmiştir. Bu bağlamda rehber dört ana başılık temelinde incelenmiştir: 1) Amaç, kapsam, dayanak, 2) Rehberlik ve denetim ilkeleri, 3) Rehberlik ve denetim esasları ve 4) Rehberlik ve denetim raporlama standartları. Bu başlıklar anahtar sözcükler olarak belirlenmiş yapılan tarama sonucunda tezler ve bilimsel hakemli dergilerde yayınlanan makaleler ile alanda yazılmış kitaplar dikkate alınarak rehber analiz edilmiştir. Bu başlıkların alt başlıklarında yer alan ifadeler anlamlı bütünler oluşturacak şekilde ayrı ayrı ele alınarak analiz edilmiştir.

Denetim rehberinin alanyazınla tutarlılığı alt probleminde denetimin tanımı, amacı (saptama, değerlendirme, geliştirme); işlevleri (bireysel, siyasal, ekonomik, toplumsal, felsefi), ilkeleri (amaçlılık, süreklilik, bütünlük, ivedilik etkileşim, bireysel farklara dikkat) ve denetim modelleri (bilimsel, sanatsal, öğretimsel, kliniksel, gelişimsel, farklılaştırılmış vb.) gibi kavramların rehberde yer alması durumu veya ilintili açıklamaların yapılıp yapılmadığı açısından incelenmiştir. Bunların ötesinde de, alanın uzmanı (lisansüstü düzeyde denetim içerikli dersler okutma, denetim alanında akademik çalışmalar yapma, BiLSEM alanında yüksek lisans tezi yürütme, seminerler düzenleme vb.) olarak içerikte literatür ile tutarsızlık gösteren durumlar da saptanmaya çalışılmıştır.

$\mathrm{Bu}$ çalışmada, elde edilen verilerin çözümlenmesinde içerik analizi tekniği kullanılmıştır. İçerik analizi, toplanan verileri açıklayabilecek kavramlara ve ilişkilere ulaşmak amacıyla yapılmaktadır. İçerik analizinde benzer özellikteki veriler, okuyucunun anlayabileceği bir biçimde belirli kavramlar ve kategoriler altında bir araya getirilerek düzenlenir ve yorumlanır (Yıldııım ve Şimşek, 2016). Bu araştırmada veriler, içerik analizi aşamaları dikkate alınarak kodlama ve ayıklama, kategori geliştirme, temaların tespit edilmesi, bulguların tanımlanması ve verilerin yorumlanması başlıkları altında analiz edilmiştir. Bu bağlamda, verilerin analizi aşamasında öncelikle rehberdeki ve gönderme yapılan yasal belgelerdeki kodlar oluşturulmuştur. Sonrasında ise elde edilen kodlar "Tutarlıık" ve "Tutarsızlık" kategorilerine dönüştürülmüştür. Bu kategoriler, "Rehberin yasal belgeler temelinde incelenmesi" ve "Rehberin alanyazın temelinde incelenmesi" şeklinde iki tema altında yer almaktadırlar. Bu analizde verilerin mutlaka nicel hale getirilmesi gerekmeyebilir ancak veriler, sayısallaştırılma yoluyla da verilebilir. Bu bağlamda, rehber incelenerek belgenin anlaşılması süreci gerçekleştirilmiş, bulgular tanımlanmış, bulgular ışığında kodlar, kategoriler ve temalar oluşturulmuştur. 
Tablolarda da sayısallaştırmadan yararlanılmıştır. Son olarak elde edilen veriyi kullanma aşamasında, belirlenen kategorilere ve alt kodlara uygun olan alıntılarla içerik analizi desteklenmiştir. Yapılan içerik analizi örneği Tablo 1'de yer almaktadır.

\section{Araştırmacının Rolü:}

Araştırmacılardan biri, lisansüstü düzeyde eğitim denetim dersi okutmakta ve denetim uygulamalarında maarif müfettişlerinin rolü, eğitim kurumlarında soruşturmalar ile BILSEM ile ilgili konu alanlarında bilimsel yayınları olan bir akademisyendir. Diğer araştırmacı, eğitim denetim dersi almış, ders süresince maarif müfettişleri ve lisansüstü öğrencilerle denetim rehberlerini tartışma ortamında bulunmuştur. Her iki araştırmacı da BiLSEM yöneticileri, maarf müfettişleri ve eğitim denetimi alanında yayınları olan öğretim üyeleriyle uzun süreli etkileşimde bulunmuş, konuyla ilgili literatürü oldukça ayrıntılı tarayarak entelektüel sermayelerini geliştirmişleridr. Araştırmacılar geniş bir mesleki ağa sahiptir. Bu anlamda sahip oldukları sosyal sermayelerinin çeşitlik göstermesi, farklı alan uzmanlarından işe dönük, işlevsel geribildirim almayı kolaylaştırmıştır.

\section{Geçerlilik ve Güvenirlik:}

Çalışmanın geçerliliğini ve güvenilirliğini sağlamak için çeşitli teknikler kullanılmıştır. Uzman incelemesi, meslektaş teyidi; verilerin karşılaştıılarak uyumunun ortaya çıkarılmasını hedefler. Uzman incelemesi yönteminde uzman, araştırma deseninden toplanan verilere, bunların analizine ve sonuçların yazımına kadar olan süreçlere eleştirel bir gözle bakar ve araştırmacıya geri bildirimde bulunur. Bu geri bildirim araştırmacı açısından kendi yaklaşımını kontrol etme ve araştırma sürecinde bu yaklaşımın olası etkilerini görme bakımından yararlı olacaktır (Yıldırım ve Şimşek, 2016). Araştırmanın geçerliğinin sağlanması için ilk olarak meslektaş teyidine gidilmiştir. Bunun için MEB Teftiş Kurulu Başkanlığı'nın farklı kurumlara yönelik denetim rehberlerini inceleyen araştırmacılar düzenli aralıklarla her hafta belirlenen gün ve saatte internet ortamında canlı toplantı araçları üzerinden bir araya gelmiştir. Tekrar izlenebilmesi için bu toplantılar kaydedilmiştir. Toplantılarda rehberlerin hangi yönlerden incelenebileceğine ilişkin tartışmalar yapılmıştır. Sonrasında ise araştırmacılar inceledikleri rehberlere yönelik içerik analizi yaparak kodlar ve kategoriler oluşturmuş ve bunların benzer ve farklı yönleri üzerinde durulmuştur. Anlaşmazlığı düşülen noktalar değerlendirilmiş ve fikir birliğine varıncaya kadar toplantılar devam etmiştir. Çözüme kavuşturulan bir anlaşmazlığa örnek vermek gerekirse, denetim rehberinin alanyazın temelinde analizinde elde edilen bulgulardan biri, rehberde yer alan denetim ilkelerinin alanyazın temelinde incelenmesi gerektiği bu noktada rehberde yer alan denetim ilkelerinde fazla ve gereksiz maddelerin olduğu yönündedir. Ancak araştırmacıların bir kısmı, denetim ilkelerinde yer verilen maddelerin rehberle örtüştüğünü gereksiz olarak ifade edilemeyeceğini dile getirmişlerdir. Ancak ilgili alanyazın taraması yapıldığında ve rehber ile karşılaştııılı̆̆ında, temel denetim ilkelerinin ortak olan kısımları analiz edilmiş ve gerekli görülmeyen maddelerin fazla ifadelendirildiği yönünde fikir birliğine varılmıştır. 
Tablo 1 BILSEM denetim rehberinin yasal belgeler ve alanyazın temelinde belirlenen kategorilere göre analiz örneklendirmesi.

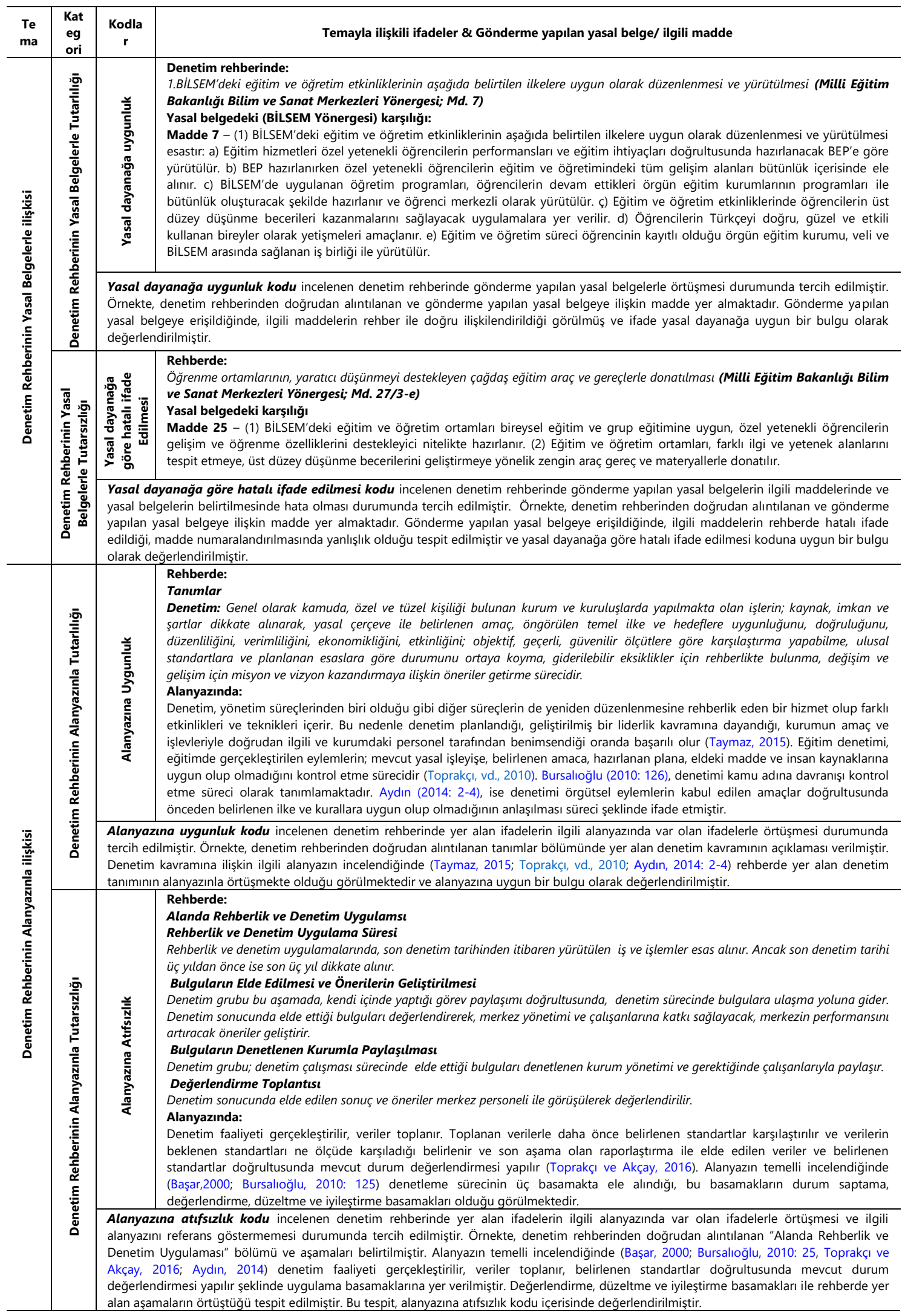


Uzman görüşü için denetim alanında yetkin ve yayımları olan bir akademisyen ile bir maarif müfettişi de çalışmada yer almıştır. Bu uzmanlar toplantı sürecinde geribildirimlerde bulunmuşlardır. Geçerlik ve güvenirliğin sağlanması için değerlendirilen rehberlerin görüş birliğine dayalı olarak analiz edilmesine ve ayrıntılı raporlaştırılmasına dikkat edilmiştir. Son toplantının ardından çalışma alanında uzman akademisyenlere gönderilmiş ve görüşleri de çalışmaya dâhil edilmiştir. Ayrıca dış güvenirliği (teyit edilebilirliği) artırmak amacıyla talep edilmesi durumunda paylaşıması ya da başka bir araştırmada karşılaştırma yapılabilmesi için araştırmanın ham verileri saklanmıştır.

\section{BULGULAR VE YORUM}

\section{BILSEM Denetim Rehberinin Yasal Belgeler Temelinde İncelenmesi}

BILSEM denetim rehberinin, yasal belgeler ve alanyazın ile tutarlılık durumlarının incelenmesi problemi kapsamında BILSEM denetim rehberinin yasal belgeler temelinde incelenmesine ilişkin bulgular Tablo 2'de verilmektedir.

Tablo 2: BILSEM denetim rehberinin yasal belgeler temelinde incelenmesi

\begin{tabular}{lllcc}
\hline Tema & Kategoriler & Kodlar & f & $\%$ \\
\hline Yasal & Tutarlıık & Yasal dayanağa uygunluk & 56 & 31 \\
Belgeler & Tutarsızlık & Yasal dayanak belirsizliği & 54 & 30 \\
& & Yasal dayanağa göre fazla ifadelendirilme & 18 & 10 \\
& & Yasal dayanağa göre güncel olmama & 17 & 9 \\
& & Illgili yasal dayanaklara eksik gönderme & 13 & 7 \\
& & Yasal dayanağın hatalı ifade edilmesi & 12 & 7 \\
& & Yasal dayanağa göre eksik ifade edilme & 10 & 6 \\
& & Toplam & 124 & 69 \\
\cline { 3 - 4 } & & Genel toplam & 180 & 100 \\
\hline
\end{tabular}

Elde edilen bulgulara göre, BILSEM denetim rehberinde tutarlılık kategorisi kapsamında tek bir kod olan yasal dayanaklara uygunluğun yer aldığı görülmekte iken; tutarsızlık kategorisi altında yasal dayanak belirsizliği, yasal dayanağa göre fazla ifadelendirilme, yasal dayanağa göre güncel olmama, ilgili yasal dayanaklara eksik gönderme, yasal dayanağın hatalı ifade edilmesi, yasal dayanağa göre eksik ifade edilme şeklinde 6 kodun olduğu görülmektedir (Tablo 3). Tablo 3'e göre denetim rehberinin tümü incelenmiş, 180 ifadede yasal belgelerle tutarlı olan kısımlarının $(n=56)$ olmasına karşın yasal belgelerle tutarsızlıklarının $(n=124)$ daha fazla olduğu görülmektedir. Bu sonuçlara göre değişik kategorilerde \%69 oranında tutarsızlık saptanmıştır. Aşağıda başıklarda tutarlılık ve tutarsızlığın hangi kategorilerde olduğu verilerek alanyazın bulgularıyla ve yorumlarla desteklenmiştir.

\subsection{Yasal belgelerle tutarlılık}

Yasal belgelerle tutarlılık teması incelendiğinde, rehberde yer alan kısımlar ile gönderme yapılan yasal belgelerin örtüşmesi durumunda incelenen 180 ifadeden, 56 kadarı yasal dayanağa uygunluk kodu içerisinde değerlendirilmiştir. 56 uygun ifade rehberde yer alan 1)Amaç, kapsam, dayanak, 2) Rehberlik ve denetim ilkeleri, 3) 
Rehberlik ve denetim esasları ve 4) Rehberlik ve denetim raporlama standartları bölümlerinden derlenmiştir.

Rehberin dayanaklar kısmı ele alındığında, rehberin dayanaklarının Anayasa'nın 42. Maddesi, 1739 sayılı Milli Eğitim Temel Kanunu'nun 56. Maddesi ve 652 sayılı KHK nın 17. Maddesi 5580 sayılı Özel Öğretim Kurumları Kanunu'nun 11'nci maddesi,5510 sayılı Sosyal Sigortalar ve Genel Sağlık Sigortası Kanunu'nun 59'ncu maddesi temelli olduğu ifade edilmektedir. Belirtilen yasal dayanakların, ilgili yasal belgelerle örtüştüğü görülmüştür. Elde edilen bu bulgu, yasal belgeye uygunluk kodu kapsamında değerlendirilmiştir. Benzer bulgular da, yasal dayanağa uygunluk kodu içerisinde ele alınmıştır.

Yasal belgelerle tutarlılık özelliği, maarif müfettişleri başkanlıkları arasında uygulama birliği ve standartlaşmayı sağlamak adına yayınlanan rehberlerde olması gerekmektedir. Weber'in bürokrasi kuramına göre bürokrasi, bir kanun ve kurallar sistemidir. Sistem genellikle kurallar, yasalar ve idari düzenlemeler ile sıralanır ve bu sistemde görevler önceden saptanmış, yazılı olarak örgüte dağıtılmış olan yönetmelik veya tüzüklere göre yerine getirilir (Weber, 1978). Denetim süreci de müfettişler tarafından belirli kurallar dâhilinde gerçekleştirilmektedir ve bürokrasi kuramına göre denetimde yapılması gereken kural ve kaidelerin rehberde yazılı hale getirildiği söylenebilir. Tutarlılık gösteren ifadeler incelendiğinde daha çok yasal metin hiyerarşisinin üst basamaklarında yer alan anayasa, KHK gibi düzenlemelerle desteklendiği, bu düzenlemelerin görece daha uzun süre değişikliğe uğramadığı, bundan dolayı da bir güncellenme ihtiyacına gerek duyulmadığı söylenebilir.

\subsection{Yasal belgelerle tutarsızlık}

Yasal belgelerle tutarsızlık kategorisi kapsamında, BILSEM denetim rehberi ile yasal belgelerin örtüşmeyen kısımları farklı kodlarda ele alınmıştır. Bu kodlar incelendiğinde yasal belgelerde tutarsızlık kategorisi içerisinde, en çok yasal dayanak belirsizliği $(n=56)$ kodunda ifadeye rastlandığı görülmektedir ve bu kodu takip eden yasal dayanağa göre fazla ifadelendirme $(n=18)$ ve yasal dayanağa göre güncel olmama $(n=17)$ kodlarının da tutarsızlık kategorisi içinde yer aldığı görülmektedir. Aşağıda, tutarsızlık kategorisi içerisinde yer alan kodlara yer verilerek alanyazın bulgularıyla ve yorumlarla desteklenmiştir.

\subsubsection{Yasal dayanağının hatalı ifade edilmesi}

Yasal dayanağın hatalı ifade edilmesi kodu kapsamında, madde hataları ve rehberde gönderme yapılan yasal belgelerde var olan hatalar ele alınmıştır. BILSEM denetim rehberinde yasal belgenin hatalı ifade edilen kısımları $(n=12)$ tespit edilmiştir.

BILSEM denetim rehberinde yer alan "BILSEM'de uygulanan programlarin her eğitim ve öğretim aşaması içinde ve süreç sonunda öğrencilere yönelik değerlendirmelerini yaparak rehberlik öğretmenine bildirmesi (Milli Eğitim Bakanlığı Bilim ve Sanat Merkezleri Yönergesi Md. 39/c) " maddesinin BİLSEM Yönergesi (2019)'ne göre incelendiğinde madde numarasında hata olduğu görülmüştür. İlgili maddenin BILSEM Yönergesi (2019) 'da "MADDE 40 - (1) Millı̂ Eğitim Bakanlığı Rehberlik ve Psikolojik Danışma Hizmetleri Yönetmeliği'nde belirtilen görevlere ilave olarak rehberlik öğretmeninin görevleri şunlardır: a) Her eğitim programı sonunda süreç ile ilgili verileri tasnif etmek, raporlaştırmak, değerlendirmeleri yapmak, değerlendirme raporlarını 
ögretmenler kuruluna sunmak." şeklinde 40/a madde numarası olarak belirtildiği görülmüştür. Bu bulgu, incelenen denetim rehberinde, yasal dayanağın hatalı ifade edilmesi kodu bağlamında değerlendirilmiştir. Madde yanlışııklarının yanı sıra yasal belgenin ifade edilmesinde de hataların olduğu görülmüştür. Örnek olarak verilen bu maddenin atıfta bulunduğu yasal dayanağın hangi yıla ilişkin olduğuna dair bir bilginin de yer almadığı bulgusuna ulaşılmıştır. Bu bulgu, denetmenler açısından bir kılavuz niteliğinde yayımlanan bu rehberde gönderme yapılan yasal belgeler ve ilgili maddelerinin, rehberin hazırlanma sürecinde doğruluğunun kontrol edilip yeterince revize edilmeden yayımlandığını düşündürtmektedir.

Denetmen tarafından rehberin hangi yıla ilişkin yasal belgeleri referans aldığının eksik olması, hangi yasal belgelere göre denetleme yapılması gerektiği konusunda eksiklikler olması, hukuki esas ve usullere uygun hazırlanılması beklenen bir rehber için eksiklik olarak değerlendirilebilir. Bürokrasi kuramına göre kurumlarda gerçekleşen yasal düzenlemeler kurumsal işleyişin herkes için anlaşılır olacak şekilde sürmesi açısından önemlidir (Weber, 2009). Denetim sürecinde kullanılan rehberde yasal belgelere ilişkin maddelerin hatalı olması, gönderme yapılan yasal belgenin yayın yılının belirsiz olması gibi bulguların yer almasının, kurum içi işleyişin bir parçası olan denetim sürecinde var olan aksaklıklardan kaynaklandığı söylenebilir. Denetim, soruşturma ya da bir suç duyurusu sürecinde, bu tutarsızlıkların hukuki bir sorun oluşturabileceği düşünülmektedir. Hatalı ifadelerin, söz konusu yönetmeliklerle çalışan işgörenlerin, bu tür hataları saptama yeterliklerinin olmaması, tespit etmeyi ve ilgili birimlere durumu iletmeyi kendi görevleri arasında görmeme ya da mesleki tükenmişliğin duyarsızlaşması açısından açıklamak mümkün olsa da, daha ileri düzeyde araştırmalarla konunun irdelenmesine gereksinim duyulmaktadır. Her yapı, işleyişteki eksikleri saptamak ve önlemlerle tekrar oluşmasını engellemek durumundadır. Bu tür hatalı ifadeleri ortaya koyacak bir yazılım ve işinin uzmanı çalışanlardan oluşacak bir takımın bu tür sorunları çözebileceği söylenebilir.

\subsubsection{Yasal dayanağa göre güncel olmama}

Yasal dayanağa göre güncel olmama kodu kapsamında denetim rehberindeki ifadenin yanında yer alan yasal belgenin güncel olmadığı ya da yürürlükten kaldırıldığı durumlar ele alınmıştır. Bu bağlamda, BiLSEM denetim rehberinde güncellenmesi gereken kısımlar $(n=17)$ tespit edilmiştir. Bu tespitlere, $d$. Elde edilen bulgulara örnek olarak, müfettişlerin görevlerine ilişkin BILSEM denetim rehberinde yer alan "a)652 sayılı Kanun Hükmünde Kararnamenin 17'nci maddesinde belirtilen görevleri yapmak" şeklinde verilen maddenin yenilenen mevzuata uygun olmaması verilebilir. MEB (2017a) yönetmeliğinde yapılan değişiklikler doğrultusunda "a)Değişik: RG-14/1/202031008) 1 sayılı Cumhurbaşkanlığı Teşkilatı Hakkında Cumhurbaşkanlığı Kararnamesinin 320'nci maddesinin birinci fikrasında belirtilen görevleri yapmak." maddesi ile güncellenmesi gerektiği bulgusuna erişilmiştir.

Denetim rehberinde kapsam ve sınırlılık bölümünde "Bu denetim rehberi hazırlanırken, Millı̂ Eğitim Bakanlığı Rehberlik ve Denetim Başkanlığı ile Maarif Müfettişleri Başkanlıkları Yönetmeliğinde belirtilen denetim hizmetlerinin çeşitleri referans alınmıştır." ifadesinin gönderme yaptığı "Milli Eğitim Bakanlığı Denetim ve Rehberlik Başkanlığı ile Maarif Müfettişleri Başkanlıkları Yönetmeliği "25.5.2014 tarihinde yürürlükten kaldırılmış, yerine 2017 yılında "Milli Eğitim Bakanlığı Teftiş Kurulu Yönetmeliği" yayınlandığı ve ilgili maddenin güncel olmadığı tespit edilmiştir. Her ne 
kadar bir sınırlılık olarak rehberde yer alan "Denetimlerde yürürlükteki hukuki düzenlemeler dikkate alınacaktır. Ayrıca denetim rehberinde yer almayan hususlar için ilgili mevzuat hükümlerine göre rehberlik ve denetim yapılacaktır. Rehberde yer alan mevzuat atıfları bilgi amaçlıdır." ifade yer alsa da denetmenlerin halen denetim sürecinde kullandıkları bir kılavuz olduğu göz önüne alındığında rehberin güncel tutulmasının önemli olduğu görülmektedir. Milli Eğitim Bakanlığı Teftiş Kurulu Başkanlığı görev, yetki, sorumluluk ve çalışma esaslarının yer aldığı yönergede Rehberlik ve Denetim Daire Başkanlığı görevleri kapsamında "Madde 25: g) Bakanlık merkez, taşra ve yurtdışı teşkilatı ile okul, kurum ve personelin rehberlik ve denetimine ilişkin esasların ve rehberlerin hazırlanması, uygulanması ve geliştirilmesine ilişkin iş ve işlemleri yürütmek," ifadesinin yer alması da rehberin güncel olması gerektiğini bulgusunu destekler niteliktedir. Buna karşın, Teftiş Kurulu Başkanlığı resmi web sayfasında yer alan denetim rehberi hazırlama sürecine ilişkin algoritma (TKB, 2020a) içerisinde güncellemeye ilişkin bir şemanın yer almaması dikkat çekicidir.

$\mathrm{Bu}$ tespitlere göre, yasal belgelerin sürekli değişmesi ve halen geleneksel metotlarla bilgiye erişim sağlanıyor olmasının da rehberin güncel olmamasında bir etken olduğu söylenebilir. İnternet teknolojileri aracılığıyla toplanan ve oluşturulan verilerin günümüzde büyük artış göstermesi ile teknolojinin bu artışa hem destek vermesi hem de çözümler üretmesi büyük veri kavramını ortaya çıkarmıştır (Öztemel, 2018). Dijitalleşmenin hız kazandığı bu çağda rehberlerin sürekli güncel tutulmasının yasal belgelere ve mevzuata ilişkin büyük verinin de sistematik hale getirilerek analiz edilmesiyle gerçekleşebileceği öngörülmektedir. Türk Eğitim sisteminde yer alan birimlerin dinamik yetenekler kuramına (Miles, 2016) göre değişimi algılaması, öğrenmesi, bütünleştirmesi ve bu noktada koordinasyon yeteneklerini kullanması beklenmektedir. Dinamik yetenekler kuramına göre denetim sisteminin dijital çağa uygun hale getirilmemiş olmasında ve rehberlerin güncel olmamasında, değişime adapte olamayan örgütlerin rol oynadığı söylenebilir. Yine ekoloji kuramına göre kurumların ve birimlerin varoluşsal nedenleri, hizmetleri ve bu hizmetlerden yararlananların yükledikleri anlam belli aralıklarla farklı araçlarla gözden geçirilmeli ve yapılarda gerekli değişiklikler sağlanmalıdır. Bu değişiklikler ile ilgili yasal metinler de oluşmuş ve güncellenmiş olacaktır.

\subsubsection{Yasal dayanağa göre eksik ifade edilme}

Yasal dayanağa göre eksik ifade edilme kodu kapsamında, yasal dayanaklarda var olan ancak rehberde eksik olarak görülen durumlar ele alınmıştır. Bu bağlamda, BiLSEM denetim rehberinde görülen eksiklikler $(n=10)$ tespit edilmiştir. Örneğin, rehberde "Denetim, Rehberlik, Rehberlik ve Denetim Bilgi işlem Sistemi, Denetim Emri, Grup Sorumlusu, Rehberlik ve Denetim Öncesi Hazırlık Toplantısı, Çalışma Planı, Bilgi Notu (Föy), Değerlendirme Toplantısı, Rapor, Raportör, Gelişim Planı" tanımlarına yer verilmiştir. Özel Eğitim Kurumları yönetmeliği 4. Maddede yer alan ve rehberde de sıklıkla geçen "Bilim ve sanat merkezleri, Özel yetenekli birey, Bireysel yetenekleri fark ettirme programı" kavramlarına ilişkin tanımlara yer verilmediği tespit edilmiştir. Bu bağlamda, BILLSEM denetim rehberinin kuruma özgü olabilmesi için BíLSEM kurumu özelinde yer alan temel tanımların da yasal belgeler doğrultusunda rehberde yer alması gerektiği düşünülmektedir. Ekoloji kuramına göre (Hannan ve Freman, 1977; Tonbul, 2020) her kurumun kendine özgü varoluşsal bir sebebi bulunmaktadır. Ekoloji kuramına göre kuruma özgü yapıların da bu doğrultuda oluştuğu söylenebilir. Denetim 
rehberlerinin her bir kurum özelinde yayınlanmış olması, denetim rehberlerinin kuruma özgü farklılıklara sahip olması gerektiği şeklinde yorumlanabilir. Sosyal kimlik kuramında, bir kurumu diğerlerinden ayıran özellikler ve uygulamaların kurum kimliğinin belirginleşmesine ve çalışanların aidiyetine arttırdığı vurgulanmaktadır. Söz konusu eksiklik BILSEM'lerin henüz kurumsal kimliğinin yeterince oluşmadığı şeklinde yorumlanabilir.

\subsubsection{Yasal dayanağa göre fazla ifadelendirme}

Yasal dayanağa göre fazla ifadelendirme kodu kapsamında, rehberde yer alan ifadelerin yasal belgelere göre fazla ifadelendirildiği durumlar ele alınmıştır. Bu bağlamda, BILSEM denetim rehberinde görülen fazla ifadeler $(n=18)$ tespit edilmiştir. Bu alt tema kapsamında ele alınan örneklerden biri, denetim ilkeleridir. Denetim ilkeleri, ilgili yasal dayanak temelinde (MEB, 2017a: 47) karşılaşılan denetim ilkeleri ile karşılaştırılarak değerlendirmesi yapılmıştır (Tablo 3).

Tablo 3: Yasal dayanağa göre fazla ifadelendirme koduna ilişkin örnek inceleme

\begin{tabular}{|c|c|}
\hline BiLSEM Denetim Rehberinden Alıntı & İlgili Yasal Belgeden Alıntı \\
\hline 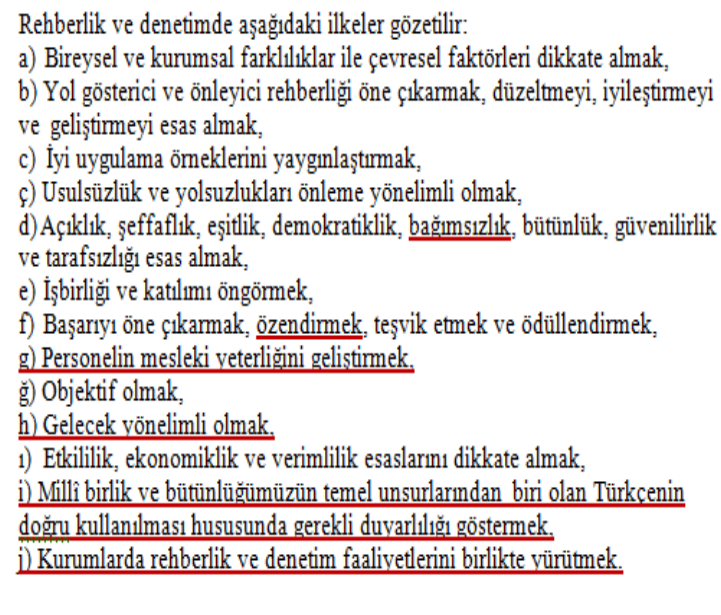 & 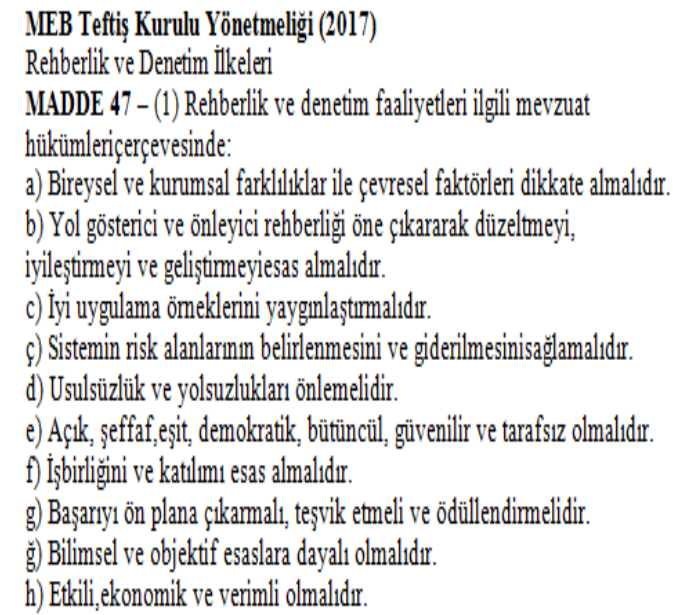 \\
\hline
\end{tabular}

Denetim rehberinde yer alan denetim ilkeleri, ilgili yasal dayanak temelinde (MEB, 2017a: 47) karşılaşılan denetim ilkeleri ile karşılaştırılarak incelendiğinde (Tablo 3) rehberde yer alan "g) Personelin mesleki yeterliğini geliştirmek, bütünsellik süreklilik, h) Gelecek yönelimli olmak, ı) Etkililik, ekonomiklik ve verimlilik esaslarını dikkate almak, i) Millî birlik ve bütünlügümmüzün temel unsurlarından biri olan Türkçenin doğru kullanılması hususunda gerekli duyarlılı̆ı göstermek) Kurumlarda rehberlik ve denetim faaliyetlerini birlikte yürütmek." maddelerinin yasal dayanağa göre fazla ifadelendirildiği tespit edilmiştir. Benzer bulgular da yasal dayanağa göre fazla ifadelendirme kodu bağlamında değerlendirilmiştir. Bu tespitlere göre, rehberde fazla ifadelendirmelerin bulunması, denetim rehberinin sade ve anlaşılır bir dile sahip olabilmesi açısından olumsuz bir özellik şeklinde yorumlanabilir. Öte yandan paydaş kuramı (Tonbul, 2020) dikkate alındığında kurumsal faaliyetlerde ve sonuçlarda pay olan kişilerin tümünün gereksinimlerini belirleme, anlama, saygı duyma ve karşılama yolu ile örgütsel etkililiği 
artırmak amacıyla fazla ifadelendirmelerin bir gereksinim olması halinde yasal metinlere eklenmesi gerektiği söylenebilir.

\subsubsection{Yasal dayanak belirsizliği}

Yasal dayanak belirsizliği kodu kapsamında yasal belgelere herhangi bir dayanağa açıkça atıf yapılmaması durumu baz alınarak, BILSEM denetim rehberinde görülen kısımlar $(n=54)$ tespit edilmiştir. BILSEM denetim rehberinde tutarsızlık durumunu oluşturan en yüksek orana sahip olan alt tema yasal dayanak belirsizliğidir. $\mathrm{Bu}$ alt temaya ilişkin bulgulardan biri, rehberde yer alan tanımların hiçbirinde yasal dayanağın bulunmamasıdır. Yasal belgelere referans gösterilmediği ve bu nedenle de yasal dayanak belirsizliğinin oluştuğu görülmüştür. Tanımların içinde yer alan denetim emri tanımında yer alan referans gösterilmeme durumu görülmüştür ve MEB Teftiş Kurulu Başkanlığı Yönetmeliği'nin 44. Maddesinde 1. Bendi "Müfettişler, görevlendirildikleri konuda valilik ve kaymakamlıklarca başlatılmış olan, inceleme ve soruşturmaların koordinasyon görevini de yerine getirirler. Işsin devralınmasını gerektirir bir durumun varlığı halinde konu gerekçesiyle birlikte Başkanlığa bildirilir. Başkanlığın bilgisi dâhilinde, mahallen yapılan çalışmalarla ilgili bilgi ve belgeler müfettiş tarafından devralınır." ifadesi göz önüne alınarak düzenlenmesi gerektiği bulgusuna erişilmiştir. Rehberde yer alan bir diğer bölüm olan ön çalışmada, rehberlik ve denetim araçlarının belirlenmesi kısmı dışındaki bilgilerin Milli Eğitim Bakanlığı Teftiş MEB Kurulu Yönetmeliği (2017) ile örtüştüğü ancak referans olarak ilgili maddelere yer verilmediği tespit edilmiştir. Yasal belgelerle tutarsızlık teması içerisinde en sık belirtilen alt tema olan yasal dayanak belirsizliğine ilişkin bu tespitler, denetim rehberlerinin hazırlanma sürecinde yasal belgelere göre revize edilmediği, kapsamlı bir şekilde ele alınmadığı ve ilgili yasal belgeleri de referans göstermediği şeklinde değerlendirilebilir. Weber' e göre örgüt içindeki sınırların ve içeriğin yasalarda açıkça belirlenmiş olması ve tanımlanmış olması, yazılı hale getirilmesi önemli bir avantajdır (Weber, 2009). Bu bağlamda denetim rehberinde yer alan ifadelerin yasal belgelere dayandırılması ve ilgili belgeleri referans göstermesinin önemli olduğu düşünülmektedir.

\subsubsection{Illgili yasal dayanaklara eksik gönderme}

Yasal dayanaklara eksik gönderme kodu kapsamında, denetim rehberinde gönderme yapılan ilgili belgede başka maddelere de atıf yapılması gerekiyorsa araştırmalar esnasında gönderme yapılan yasal belgeler dışında başka destekleyici belgelere de ulaşıldıysa fakat bunlara denetim rehberinde değinilmediği durumlar incelenmiştir ve bu bağlamda BILSEM denetim rehberinde görülen kısımlar $(n=13)$ tespit edilmiştir. Bu tespitlere, aşılmıştır. Bu koda ilişkin, rehberde merkezi fiziki koşullar kısmında yer alan "Lojmanı bulunan merkezlerde; lojman tahsislerinin yapılma durumu (Kamu Konutları Yönetmeliği, MEB 2012/8 Sayılı Genelge)" maddede kamu kurumları yönetmeliğine gönderme yapılmış olması örnek verilebilir. Bu ifade analiz edildiğinde, ifadeye ilişkin "Öğretmen konutları: 1739 MEB Temel kanunu Madde 50 Milli Eğitim Bakanlığınca gerekli görülen yerlerde, özellikle mahrumiyet bölgelerinde görevli öğretmenlere konut sağlanır. Konutlar okul binaları ile birlikte planlanır ve yapılır. " şeklinde de bir madde yer almakta ve 1739 MEB temel kanunu 50. Maddeye gönderme yapılmadığı bulgusuna erişilmiştir. Benzer bulgular da ilgili yasal dayanaklara eksik gönderme kodu bağlamında değerlendirilmiştir. 
Rehberin yasal belgelerle tutarlılığının incelenmesine ilişkin elde edilen bulgular genel olarak değerlendirildiğinde, BILSEM denetim rehberinin yasal belgelere tutarlılık oranı \%31 iken, tutarsızlık oranının \%69 olduğu görülmektedir (Grafik 1). Bu sonuca göre BILSEM denetim rehberinin yasal dayanaklara uygun olan kısımlarının var olmasına rağmen, birçok açıdan yasal belgeler ile tutarsızlıklar gösterdiği görülmüştür. Çağımızda eğitim denetimi, eğitim alanının bir bilim dalı haline gelmiş ve eğitim denetçiliği profesyonel bir meslek olarak kabul edilmiştir (Gündüz ve Balyer, 2012).

Denetim bilimi bir bilimde olması gereken özellikler (Toprakçı vd., 2010) bakımından incelendiğinde; Bir bilim olarak, inceleme alanı insanlar,

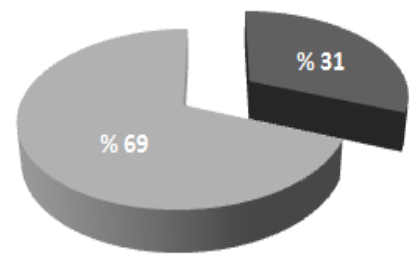
- Tutarlılık $\quad$ Tutarsızlik

Grafik 1. BİLSEM Denetim Rehberinin yasal belgelere göre tutarlilik durumu(\%). örgütler ve yönetim süreçlerinin değerlendirme kısmı olduğu, denetim süreçleri incelendiğinde, bilimsel metotlara dayanarak standartların belirlenmesi ve karşılaştırılmasına yönelik sistematik bir yönetsel faaliyet olduğu (Doğan, 2015) görülmektedir. Denetim bir bilim olarak bilimsel araştırma basamaklarını temel alır. Her denetsel faaliyet bir bilimsel faaliyettir ve denetmen denetim sürecinde bu basamakları takip ederek eğitim denetimini gerçekleştirir (Toprakçı, 2020). Denetim raporlarının da bilimsel olması gerekmekte ve buna kılavuz olması için hazırlanan rehberin de bilimsel bir yazıda olması gereken özelliklere sahip olması gerektiği düşünülmektedir. Yasal dayanak belirsizlikleri, atıfların eksik ya da hatalı olması ve son güncellenen yasal belgelere dayandırılmamış olması, rehberin tutarsızlık yüzdesinin de bunu destekler nitelikte olduğu görülmektedir.

Tutarsızlıklara ilişkin bulgular genel olarak ele alındığında, denetmenlerin hesapverilebilirlik ilkesine göre tespit edilen eksiklikleri iletebilecekleri bir denetim mekanizmasının olmaması, bu kapsamda oluşturulmuş bir birimin bulunmaması rehberdeki tutarsızlıklara neden olabileceği söylenebilir. Hesap verebilirlik ilkesi, kişilerin yetkilerini kullanmalarından ve yapmış oldukları faaliyetlerden sorumlu olmalarını ifade eder. Kişiler veya kurumlar aldıkları karardan etkilenecek kişilere karşı sorumluluklarından ötürü hesap vermeleri gerekir (Göker ve Gündüz, 2017). Bunun yanı sıra, denetim rehberinde denetmenlerin tespit ettikleri eksiklikleri iletebilecek bir özgürlüğe sahip olmaları ve bu doğrultuda iletilen sorunların karşılık bulduğu düzenleyici yapıların oluşturulması beklenmektedir. Kurumsal aidiyet, bireyin kurumun misyon ve vizyonunu benimsemesini ve kurumda var olma isteğini göstermesidir (Hiriyappa, 2009). Tutarsızlıkların görülme sıklığındaki fazlalığının (\%69) nedenlerini ortaya koymak, bu araştırmanın problem durumunu oluşturmamakla birlikte, bu tür olumsuzlukların nedenlerini irdeleyen kuramlar (örneğin Kaos, Bürokrasi, Kurumsal Kuram vb.) açısından yaklaşıldığında kısaca şöyle bir yorum yapılabilir: Kurumsal işleyişte eksikleri saptamakla doğrudan ilgili birimlerde ve çalışanlarda görev tanımlarında, uzmanlık, aidiyet, örgütsel vatandaşlık alanlarında sorunlar olduğu söylenebilir. Yapılacak farklı araştırmalarla bu sorunların nedenleri irdelenebilir. 


\section{BILSEM Denetim Rehberinin Alanyazın Temelinde İncelenmesi}

BILSEM denetim rehberinin, alanyazın ve yasal belgelerle tutarlılık durumlarının incelenmesi problemi kapsamında BILSEM denetim rehberinin alanyazın ile tutarlılık durumuna ilişkin bulgular Tablo 4'te verilmektedir.

Tablo 4: BILSEM denetim rehberinin alanyazın temelinde incelenmesi

\begin{tabular}{lll}
\hline Tema & Kategoriler & Kodlar \\
\hline Alanyazın & Tutarlıık & Alanyazına uygunluk \\
& Tutarsızlık & İcerik eksikliği \\
& Alanyazına atıfsılık \\
& Kavram tutarsızığı \\
& Alanyazın ile aykırı durum \\
\hline
\end{tabular}

Elde edilen bulguların kodlara göre tutarlılık durumları incelendiğinde BILLSEM denetim rehberinde tutarlılık kategorisi kapsamında tek bir kod olan alanyazına uygunluk ifadesinin yer aldığı görülmekte iken; tutarsızlık teması altında alanyazın ile aykırı durum, alanyazına atıf, içerik eksikliği, kavram tutarsızlığı şeklinde 4 kodun ortaya çıktığı görülmektedir (Tablo 4). Tablo 4'e göre denetim rehberinin alanyazınla tutarsız olan maddelerinin olmasına karşın, denetim rehberinin genel anlamda alanyazınla tutarlıık gösterdiği görülmektedir. Bu tespite bakıldığında, alanyazın ile tutarlılığının, tutarsızlığına göre daha fazla olması beklenen bir bulgu olarak karşımıza çıkmaktadır ve alanyazına uygunluk koduna ilişkin bulgular denetim rehberi açısından sevindiricidir.

\subsection{Alanyazın ile tutarlılık}

Alanyazın ile tutarlılık kategorisi incelendiğinde alanyazına uygunluk kodu BíLSEM denetim rehberi ile alanyazının örtüşen kısımları kapsamında oluşturulmuştur. Örnek vermek gerekirse, denetim sürecine ilişkin bölümünün rehberde yer aldığı görülmüştür. Alanyazın temelli incelendiğinde (Başar, 2000: 5; Bursalıŏlu, 2010: 125) denetleme sürecinin üç basamakta ele alındığı, bu basamakların durum saptama, değerlendirme, düzeltme ve iyileştirme basamakları olduğu görülmektedir. Rehberde yer alan veri toplama sürecinin olması ve tekniklerin belirlenmesi, denetim öncesi hazırlık ifadelerinin örtüştüğü görülmekte ve elde edilen bu bulgular alanyazınla tutarlılık olarak değerlendirilmiştir.

Bir diğer örnek olarak ise, denetim ilkelerinin yer aldığı alanyazın incelenerek denetim rehberinde verilen denetim ilkeleri ile karşılaştırma yapılmıştır. Bu karşılaştırmalar alanyazında yer alan denetim ilkeleri (Aydın, 1993; Baransel, 1979; Burton. W.H. ve Leo Brueckner,1966; Akt. Gökçe, 1994; Başar, 2000) temelinde yapılmıştır. Karşılaştırma öncelikle kelimelerin birebir geçip geçmeme durumuna göre yapılmıştır. Buna göre demokratiklik, süreklilik, bütünsellik, objektiflik /tarafsızlık, açıklık ilkelerinin rehberde yer aldığı görülmüştür. Rehberin alanyazınla örtüşmekte olduğu görülmüştür. Alanyazına uygunluk koduna ilişkin elde edilen bu tespitlere göre, eğitim denetimi bilimi kapsamında üretilen bilginin rehberde karşılığının bulunduğu ve bu bilgilerin rehberde kullanıldığı söylenebilir. 


\subsection{Alanyazın ile tutarsızlık}

Alanyazın ile tutarsızlık kategorisi kapsamında, BILSEM denetim rehberi ile alanyazının örtüşmeyen kısımları farklı kodlarda ele alınmıştır. Bu kodlar alanyazın ile aykırı durum, alanyazın desteğinin olmaması, içerik eksikliği, kavram tutarsızlığı şeklindedir.

\subsubsection{Alanyazın ile aykırı durum}

Alanyazın ile aykırı durum kodu kapsamında, BILSEM denetim rehberinde görülen kısımlar tespit edilmiştir. Örnek vermek gerekirse, bu koda ilişkin bulgulardan biri denetim ilkeleri bölümüdür. Bu bölüm bağlamında, rehberde anlamsal ve birebir geçme anlamında tüm ilkelere yer verildiği, sadece " i)Millî birlik ve bütünlügü̈müzün temel unsurlarından biri olan Türkçenin doğru kullanılması hususunda gerekli duyarlıı̆ı göstermek," ilkesinin alan yazın temelli (Aydın, 1993; Baransel, 1979; Burton. W.H. ve Leo Brueckner,1966; Akt. Gökçe, 1994; Başar, 2000) incelenen denetim ilkeleri ile örtüşmemesi, alanyazına aykırı bir durum olarak değerlendirilmiştir. Eğitimde denetimin ilkeleri, denetim sürecini etkileyen değişkenler arasındaki ilişkileri açıklamaktadır. Denetim ilkeleri, denetim uygulamalarına yol gösterici rol oynayarak uygulama sonuçlarını kestirmeyi sağlamaktadır (Gökçe, 1994). Rehberde yer alan birçok ilkenin alanyazınla örtüşmesine karşın, alanyazında verilen denetim ilkeleri ile örtüşmeyen maddelerin de rehberde bulunması, denetim süreci ve denetmen açısından olumsuz bir tespit olarak değerlendirilebilir.

\subsubsection{Alanyazına atıfsızık}

Atıfsızlık, rehberin alanyazınla ilişkisi tutarlı ya da tutarsız olsun rehberin konusu ile ilgili yapılmış bilimsel çalışmalara gönderme yapmama durumunu ifade etmektedir. Alanyazına atıfsızlık kodu kapsamında, BILSEM denetim rehberinde görülen kısımlar tespit edilmiştir. BILSEM denetim rehberi, incelendiğinde rehberin alanyazına herhangi bir göndermede bulunmadığı, alanyazın ile desteklenmediği görülmektedir.

Örneğin, denetim rehberinde yer alan 'Denetim Rehberinin Kapsam ve Sınırlılığı' bölümüne bakıldığında, rehberin hazırlanmasında alanyazın bulgularının da dikkate alındığına dair bir bilgiye rastlanmamıştır. Bu koda ilişkin örnek Tablo 5 'te verilmiştir.

Tablo 5:Yasal dayanağa göre atıfsızlık koduna ilişkin örnek.

\begin{tabular}{l} 
BILSEM Denetim Rehberinden Alıntı \\
\hline IV. DENETiM REHBERININ KAPSAM VE SINIRLILIĞı \\
'Bu denetim rehberi hazırlanırken, Milî̀ Eğitim Bakanlığı Rehberlik ve Denetim Başkanlığı ille Maarif \\
Müfettişleri Başkanlıkları Yönetmeliğinde belirtilen denetim hizmetlerinin çeşitleri referans alınmıştır.' \\
\hline
\end{tabular}

Alanyazında yer alan bu bilgi birikiminden de yararlanıldığına dair ifadenin, denetim rehberi hazırlanırken yer almasının, olumlu olacağı düşünülmektedir. Bakanlığın bu yöndeki tutumu, akademik alanda yapılacak denetim araştırmalarının niteliğini artırabileceği düşünülmektedir.

\subsection{3. İçerik eksikliği}

İçerik eksikliği kodu kapsamında, alanyazında olan ancak denetim rehberinde olmayan ifadeler ele alınmıştır ve bu bağlamda BILSEM denetim rehberinde görülen kısımlar tespit edilmiştir. Örneğin, rehberde yer alan tanımlar bölümünde, BILSEM 
kurumu, özel yetenekliler, üstün yetenekliler kavramları ile ilgili bir tanıma yer verilmemesidir. Alanyazında bu tanımlar incelendiğinde, "Milli Eğitim Bakanlığı Özel Eğitim Konseyi " Raporuna göre, "üstün zekâ" ve "üstün özel yetenek" kavramları "üstün yetenek" başlığı altında "üstün yetenekliler, konunun uzmanları tarafından genel ve/veya özel yetenekleri kıyaslandığında yaşıtlarına göre yüksek düzeyde performans gösterdiği belirlenmiş kişiler" olarak ifade edilmiştir (Sak., vd.,, 2015). Avcı ve Ersoy'a (2000) göre günümüzde "üstün yetenekli" ve "üstün zekâlı" kavramları ayrı düşünülemez ve "üstün zekâ üstün yetenek" içinde tanımlanabilmektedir. Rehberde yer verilmeyen bu tanımlar rehberde içerik eksikliği olarak değerlendirilmiştir. Bu koda ilişkin örneklerden biri de, rehberde yer alan denetim ilkelerinin alanyazında yer alan denetim ilkeleri (Aydın, 1993; Baransel, 1979; Burton. W.H. ve Leo Brueckner,1966; Akt. Gökçe, 1994; Başar, 2000) ile karşılaştırıldığında süreklilik ve hesapverilebilirlik ilkelerinin yer almadığı bulgusudur.

Denetim rehberinde içerik eksikliği kodunda saptanan bir diğer eksiklik ise denetimin eğitim felsefesi ile ilişkilendirildiğine dair hiçbir içeriğin yer almamasıdır. Oysa denetim yaklaşımı, belirlenen eğitim felsefesi ile koşutluk göstermelidir. Temel eğitim felsefesi ilerlemecilik ve yeniden yapılandırmacılık ise, denetimin de bu felsefelere göre yapılandırılması gerekliliği ile ilgili ifadelerin yer alması beklenirdi. Diğer bir eksiklik ise rehberde denetim modelleri ile ilgili ifadelerin yokluğudur. Denetim rehberi, denetmene duruma göre gerekli denetim modellerini (sanatsal, bilimsel, kliniksel, öğretimsel, farklılaştırımış vb.) işe koşmakla ilgili yönlendirmelerin yer alması beklenirdi. Rehberde 2.3.3. Kurum-Çevre İlişkileri başıı̆ı altında' maddesi ile BILSEM yönergesindeki karşıı̆ı birebir aynıdır. Oysa rehberin daha açıklayıcı olması beklenir. Rehberde, yönergeden farklı olarak söz konusu işbirliğinden ne anlaşıldığı ayrıntılı olarak belirtilmesi beklenirdi. Aşağıda rehber ve yönergedeki ifadeler doğrudan aktarılmıştır.

Yönerge: 'Eğitim ve öğretim süreci öğrencinin kayıtlı olduğu örgün eğitim kurumu, veli ve BILSEM arasında sağlanan iş birliği ile yürütülür.'( Madde 7-1/e)

Rehber: Eğitim öğretim sürecinde; öğrencinin kayıtlı olduğu örgün eğitim kurumu, veli ve merkez arasında iş birliğinin sağlanması' (2.3.3 Kurum çevre Illişkileri)

İçerik eksikliği koduna ilişkin ifadelerin bulunmasının temelinde denetim rehberinin hazırlanmasında, ulusal ve uluslararası alanyazın bilgilerine yeterince başvurulmaması, BILSEM gibi bir kurumun kendine özgü yönlerinin (felsefesi, buralara uygulanacak denetim modelleri) bir de denetim açısından yeterince dikkate alınmamış olması gibi nedenler sayılabilir. BILLSEM, çok özel bir modeldir ve buraların denetimi ayrı bir uzmanlık gerektirir. Öğretmenleri de öğrencileri de seçilerek oluşturulan bu kurumların deneticilerinin de özel bir eğitim ihtiyacı olduğu düşünülmektedir. Müfettişlerin yetiştirilmesinde yaşanılan sorunlar arasında olan 'kurum odaklı denetim' bilgisi eksikliği, rehberde daha açık ifadelerle yer verilmesi uygun olurdu. Bu durum, denetimin belirli boyutlarından sorumlu olan yöneticiler için de geçerlidir.

\subsubsection{Kavram tutarsızlığı}

Kavram tutarsızlığı kodu kapsamında, BILSEM denetim rehberinde görülen kısımlar tespit edilmiştir. Bu koda ilişkin bulgulardan biri, rehberde yer alan denetim ilkelerinin ifade ediliş biçimidir. Denetimi yapacak kişiler açısından daha açık bir şekilde ifade edilmesi gerektiği, aynı ilkeyi ifade eden maddelerin tekrarından kaçınılması gerektiği görülmüş ve bu durum kavram tutarsızlığı olarak değerlendirilmiştir. 
Koda ilişkin bir diğer bulgu ise, denetim rehberinde tanımlardan itibaren rehberlik ve denetim kavramları ayrı olarak ifade edilmesidir. Ancak denetim kavramının alanyazında rehberlik kavramını kapsadığı görülmüştür. Alanyazında "Konuşma dilinde denetim anlamını taşıyan ve/veya aynı anlamda kullanılan "araştırma, kovuşturma, soruşturma, inceleme, revizyon, kontrol, teftiş, murakabe vb." birçok sözcük vardir. Türkiye'de denetleme kavramı, daha çok ağırlıklı olarak revizyon, kontrol, murakabe ve teftiş sözcüklerinde kendisini bulmaktadır (Pekiner, 1988; Akt. Sabancı vd., 2016 )." şeklinde belirtilmektedir. Elde edilen bu bulgu rehberin alanyazın ile olan kavram tutarsızlığı olarak yorumlanmıştır. Denetim ve rehberlik kavramları ilişkisine bakıldığında denetim kavramının içindeki rehberlik kavramı çıkarılmalıdır. Denetim tek bir tanım ve ifade olarak kalmalıdır. Denetim rehberinde yer alan bu ifade karmaşasının bulunması, rehberin anlaşılırlığını ve uygulanabilirliğini azaltan bir etken olarak yorumlanabilir.

Rehberin alanyazın ile tutarlılığının incelenmesine ilişkin elde edilen bulgular genel olarak değerlendirildiğinde, BILSEM denetim rehberinin alanyazınla genel olarak tutarlılığa sahip olduğu, denetim bilimine ilişkin üretilen bilgilerin rehberde yer bulduğu görülmektedir. BiLSEM'ler, bireylerin özel yeteneklerinin keşfedilmesi, bu yönde gelişimlerinin sağlanarak ülkeye değer katmaları için oluşturulmuş özel kurumlardır. Buralardan yetişecek olan bireyler, Kaos Kuramında dile getirilen kelebek etkisi yaratma potansiyeline sahip oldukları düşünülmektedir. Bu kurumlarda eğitim gören çocukların, Sosyal Kolaylaştırma Kuramı́na göre normal devam ettikleri örgün eğitim kurumlarındaki eğitimsel ve öğretimsel uygulamalara da renk katacakları, diğerlerini güdüleyecekleri varsayılabilir. Bu çocuklara özel birtakım anlamlar yüklerken, başarının yetenek kadar çabaya da atfedilmesi hususunda kurum yöneticisine ve öğretmenlerine çok iş düşmektedir. Bu işlerin kolaylaştırılmasının da rehberin yeterliliğine bağlı olduğu söylenebilir. BiLSEM Denetim Rehberi genel olarak, alanyazında üretilmiş bilgilerle uyumlu olmakla birlikte, içeriğinin kuruma özgü ifadelerle yukarıda belirtilen eksiklerin giderilerek zenginleştirilmesi gerektiği düşünülmektedir.

\section{SONUÇ VE ÖNERILER}

Araştırmanın bu bölümünde elde edilen sonuçlar dikkate alınarak önerilere yer verilmiştir. Çalışmada ilk alt amaç olan rehberin yasal belgeler temelinde incelenmesine ilişkin sonuçlara bakıldığında, rehberin yasal belgelerle tutarlı olan kısımlarının olmasına karşın, tutarsızlık gösteren çok sayıda madde de bulunmuştur. Yasal belgelerle tutarsızlık kategorisinde yer alan kodlara ilişkin sonuçlar incelendiğinde, en çok ifadeye yasal dayanak belirsizliği kodunda rastlanmıştır. Bu kodu takip eden yasal dayanağa göre fazla ifadelendirme ve yasal dayanağa göre güncel olmama kodlarının da tutarsızlık kategorisi içinde yer aldığı görülmüştür.

Tutarsızlık kategorisi altında "Yasal dayanak belirsizliği" kodunun ön plana çıktığı ve BiLSEM denetim rehberinin çoğunlukla yasal belgeleri referans olarak göstermediği sonucuna ulaşılmıştır. Uygulayıcılar açısından, eksikliğin giderilebilmesi için kılavuz niteliğinde hazırlanmış olan bu rehberi gözden geçirecek, denetim alanında uzman ve rehber hazırlama konusunda bilgili bir ekip görevlendirilebilir. Bu ekipte BILSEM denetiminde tecrübeli maarif müfettişlerinin yanı sıra, eğitim denetimi alanında uzmanlaşmış öğretim üyeleri, hukukçular, metnin dilinin düzenlenmesinde Türkçe 
eğitimi uzmanları yer alabilir. Ekip, hesapverilebilirlik ilkesine uygun şekilde, saptanan hataları önerileriyle birlikte ilgili birimlere ileterek, yasal dayanak belirsizliğinin en aza indirgenmesine, eksik yasal belge atıflarının rehbere eklenmesine, yasal belgelere göre fazla ifadelendirmelerin saptanarak sadeleştirilmesine ve rehberin güncelleştirilmesine katkı sağlayabilir. Ekip alanyazını tarayarak buradaki gelişmelerin, bulguların ve yaklaşımların rehbere yansımasına, gerektiği yerlerde atıf yapılarak uygulayıcılar açısından rehbere bilimsel bir nitelik kazandırmaya; kavram tutarsızlıklarının giderilmesine, içerik eksikliğinin giderilerek kurumun (BILSEM) kendine özgü yönlerinin de daha fazla öne çıkmasına katkı sağlayabilir.

Yasal belgelerin güncellenmesi denetim sisteminin dijitalleştirilmesi önerilebilir. MEB tarafından 2023 Vizyon Belgesi'nde dijitalleşme sürecinde mevzuata ilişkin en çok vurgulanan büyük verinin ele alınmasının, denetim sisteminin dijitalleşmesinin temel noktası olacağı düşünülmektedir. Denetim rehberinin gönderme yaptığı tüm yasal belgelerin ulaşılabilirliği açısından da bir yazılım geliştirilerek tüm alt veri tabanlarının tek bir veri tabanı oluşturularak birleştirilmesi önerilmektedir. Bu şekilde, dijitalleşen bir denetim sisteminde denetim rehberlerinin de kullanıc dostu olması sağlanabilecektir. Eğitim denetimi alanında çalışmakta olan araştırmacıların, bilişim alanında uzmanlar akademisyenler ile iş birliği yaparak bir yazılım geliştirmeleri ve bu yazılımın kullanımına yönelik araştırmalar yapılabilir.

Müfettiş yardımcısı yetiştirme sürecinde, rehber hazırlama ve veri analizi eğitimlerine yer verilebilir. Kurumların farkları da bu eğitimlerin içeriğine yansıması gerekmektedir ve bu doğrultuda BíLSEM türü kurumların denetiminde uzmanlaşmış denetçilerin sayısının artırılabilir. Denetim görevinin büyük oranda kurum yöneticilerine verildiği düşünüldüğünde, BILLSEM yöneticileri de denetim rehberini uygulamaya geçirme konusunda eğitimler alabilirler.

Eğitim yönetimi bilim dalı lisansüstü programlarında, eğitim denetimi alanında verilen derslerin içeriğinde, denetim rehberi gibi belgelerin nasıl hazırlanması gerektiğine ilişkin içerikler, öğretim programına eklenebilir. Bu programlarda, BILSEM türü kurumların denetimi ile ilgili içeriklere de yer verilebilir.

Yasal belgelerle ve alanyazınla ortaya çıkan tutarsızlıkların nedenlerini belirlemek, tutarsızlıkların yol açtığı veya açma olasılığı durumları ortaya çıkarmak, tüm bunların sonunda uygulayıcılara ve araştırmacılara öneriler geliştirmek amacıyla da araştırmalar yapılabilir. Denetim rehberini uygulayan kurum yöneticileri ve maarif müfettişleri ile görüşmeler yapılabilir. Bu araştırmada ortaya konan tutarsızlıklar dikkate alınarak yeni bir rehberin yazımı için bir proje yapılabilir. Doküman analizi tekniğiyle elde edilen bu araştırmanın sonuçları, başka araştırmalarda derinleştirebilir. Çalışmada gerçekleştirilen analize ilişkin ham verilerin saklanmış olması, gelecekte yapılacak olan araştırmalar ve rehberin eksiklerinin giderilmesi için bir temel oluşturabileceği düşünülmektedir.

\section{KAYNAKLAR}

Atay, K. (1995). Ilköğretim müfettişlerinin yeterlikleri, Yayınlanmamış Doktora Tezi, Atatürk Üniversitesi Sosyal Bilimler Enstitüsü, Erzurum.

Aydın, M. (2014). Çağdaş eğitim denetimi. Ankara: Gazi Kitabevi. 
Avcı, N., \& Ersoy, Ö. (2000). Özel gereksinimli olan çocuklar ve eğitimleri. İstanbul: Ya-Pa Yayıncilık.

Bapoğlu Dümenci, S., Gürsoy, F., \& Aral, N. (2016). Türkiye'de okul öncesi dönemdeki üstün potansiyelli ve üstün zekâlı olan çocukların eğitimleri. Kastamonu Eğitim Dergisi, 24(5), 2469-2480.

Başar, H. (2000). Eğitimde çağdaş denetim yaklaşımları. Eğitim denetçisi. Ankara: Pegem-A Yayıncilık.

Bursalıoğlu, Z. (2010). Eğitim yönetiminde teori ve uygulama. Ankara: Pegem A Yayınları, 9.Baskı.

Can, E. \& Gündüz, Y. (2019). Eğitimin denetimi uzmanlığı gerektirir mi?. Millî Eğitim Dergisi, 48(221), 187-205.

Çakırer, I., Bilbay, A., Bagcivan, E., \& Bayraktutan, I. (2010). Kuram ve uygulamada eğitim denetmenleri meslek etiği. Educational Policy Analysis and Strategic Research, 5(1), 1423.

Çoban, G. S. (2018). Bilim ve sanat merkezleri yöneticilerinin yaşadıkları zorluklar ve çz̈züm yollarına ilişkin görüşleri: Istanbul örneği (Yüksek Lisans Tezi, İstanbul Kültür Üniversitesi/Sosyal Bilimler Enstitüsü/Eğitim Bilimleri Anabilim Dalı).

Doğan, K. C. (2015). Yönetimin bir fonksiyonu olarak denetim ve kamu yönetimindeki yeri. Ombudsman Akademik, (3), 107-141

Friel, N. (2015). The cinderella of education: gifted and talented pupils, with a focus on double exceptionality. http://www.divaportal.org/smash/record.jsf?pid=diva2\%3A838839\&dswid=-8678 27 Ağustos 2020.

Gökçe, F. (1994). Eğitimde denetimin amaç ve ilkeleri. Hacettepe Üniversitesi Eğitim Fakültesi Dergisi, 10(10), 73-78.

Göker, S. D., \& Gündüz, Y. (2017). Eğitim denetimi sürecinde hesap verebilirlik ve şeffaflık uygulamaları. Ondokuz Mayıs Üniversitesi Eğitim Fakültesi Dergisi, 36(1), 83-93.

Gündüz, Y., \& Balyer, A. (2012). Türkiye'de ve Bazı Avrupa ülkelerinde müfettişlerin yetiştirilme süreci ve karşılaşılan sorunlar. Mersin Üniversitesi Eğitim Fakültesi Dergisi, 8(1), 84-95.

Güneş, A. (2018). Türkiye'de bilim sanat merkezleri. Avrasya Sosyal ve Ekonomi Araştırmaları Dergisi, 5(6), 185-193.

Hizlı, E. (2014). Examining of gifted and talented education: Israeli Education. Journal of Gifted Education Research, 2(2), 52-62.

Hırıyappa, B. (2009). Organizational behavior. New Age International, Delphi.

İlğan, A. (2008). Illköğretim müfettişleri ve öğretmenlerinin farklılaştırılmış denetim modelini benimseme ve uygulanabilir bulma düzeyleri. Kuram ve Uygulamada Eğitim Yönetimi, $55,389-422$.

Kayıkçı, K. (2005). Milli Eğitim Bakanlığı müfettişlerinin denetim sisteminin yapısal sorunlarına ilişkin algıları ve iş doyum düzeyleri. Kuram ve Uygulamada Eğitim Yönetimi Dergisi, 11(4), 507-527.

Kayıkçı, K., Özdemir, I., \& Özyıldırım, G. (2018). Okul yöneticisi seçme ve yerleştirme uygulamasına ilişkin bir değerlendirme: Görev süresi dolan okul müdürlerinin, yeniden görevlendirilme usullerine ilişkin görüşleri. Electronic Journal of Social Sciences, 17(67), 874-888.

Kayıkçı, K., \& Emiroğlu, S. E. (2014). Görevsel örgüt yapısına göre düzenlenmiş eğitim denetimi gruplarının çalışmalarının değerlendirilmesi: İstanbul örnek uygulaması. Milli Eğitim Dergisi, 44(201), 60-82.

Kazu, I.Y. \& Şenol, C.(2012). Üstün yetenekliler eğitim programlarına ilişkin öğretmen görüşleri (BiLSEM Örneği). E-international Journal of Educational Research, 3(2),13-35.

Keskin, M. Ö., Samancı, N. K., ve Aydın, S. (2013). Bilim ve sanat merkezleri: Mevcut durumları, sorunları ve çözüm önerileri. Üstün Yetenekli Eğitimi Araştırmaları Dergisi, 1(2), Özel Sayı, 78-96.

Kılıç, V. C. (2018). Üstün zekâlı ve yetenekli çocukların eğitiminde ülke politikaları ve eğitim uygulamaları. Türk Kültürü Araştırma Enstitüsü. 135-143. 
Koç, İ. (2016). Üstün zekâlı ve üstün yetenekli öğrenci velilerinin Bilim ve Sanat Merkezi'yle ilgili görüşleri: Bir BíLSEM örneği. Üstün Zekâlılar Eğitimi ve Yaratıcılık Dergisi, 3(3), 17-24.

Kurnaz, A. (2014). Yirminci yılında bilim ve sanat merkezlerinin raporlar ve yönetici görüşlerine dayalı olarak değerlendirilmesi. Üstün Yetenekliler Eğitimi Araştırmaları Dergisi, 2(1), 122.

Lillis, K. M. (1992). Improving basic education: preconditions for successful inspectionand supervision: implications for training." International Institute for Educational Planning, UNESCO. http://birbhum.nic.in/DPSC/reference/95.pdf , 25 Eylül 2020.

MEB BiLSEM Yönergesi, (2019). Milli Eğitim Bakanlığı Bilim ve Sanat Merkezleri Yönergesi. http://orgm.meb.gov.tr/meb_iys_dosyalar/2020_03/04161158_FW_BYLYM_VE_SANAT_ MERKEZLERY_YONERGESY_.zip , 10 Eylül 2020.

MEB. (2016). Milli eğitim bakanlığı rehberlik ve denetim başkanlığı ile maarif müfettişleri başkanlıkları yönetmeliğinde değişiklik yapılmasına dair yönetmelik. Resmi Gazete, 16.03.2016 tarih 29655 sayı. https://www.resmigazete.gov.tr/eskiler/2016/03/201603167.htm 9 Ekim 2020.

MEB, (2017a). Milli Eğitim Bakanlığı Teftiş Kurulu Yönetmeliği, Tebliğler Dergisi, 30160.

MEB. (2020). Özel Eğitim ve Rehberlik Hizmetleri Genel Müdürlüğü https://orgm.meb.gov.tr , 18 Ağustos 2020.

MEB. (1997). Özel Eğitim Hakkında Kanun Hükmünde Kararname. Erişim adresi: https://www.mevzuat.gov.tr/MevzuatMetin/4.5.573.pdf, 17 Ağustos 2020

Milli Eğitim Bakanlığı. (2020). Teftiş Kurulu Başkanlığı Birimler. Erişim adresi: https://tkb.meb.gov.tr/ 14 Temmuz 2020.

Miles, J. (2016). Yönetim ve organizasyon kuramları. Nobel Akademik Yayıncılık.

NAGC. (2019). National Association for Gifted Children https://www.nagc.org/ 18 Haziran 2020.

Özen, F., \& Hendekçi, E. A. (2016). Türkiye'de eğitim denetimi alanında 2005-2015 yılları arasında yayımlanan makale ve tezlerin betimsel analizi. OPUS Uluslararası Toplum Araştırmaları Dergisi, 6(11), 619-650.

Özel eğitim hizmetleri yönetmeliği. (2018). Resmi Gazete, 30471, 07.07. https://www.resmigazete.gov.tr/eskiler/2018/07/20180707-8.htm, 14 Eylül 2020

Özsoy, Y., Saldıroğlu, H., \& Sever, M. (1991). Üstün yetenekli çocuklar ve eğitimleri Ön Raporu. Ankara: TC Milli Eğitim Bakanlığı Özel Eğitim ve Rehberlik Dairesi Başkanlığı.

Öztemel, E. (2018). Eğitimde yeni yönelimlerin değerlendirilmesi ve Eğitim 4.0., Üniversite Araştırmaları Dergisi, 1(1), 25-30.

MEB (1973). Milli eğitim temel kanunu. Kanun Numarası, 1739. Erişim adresi: https://www.mevzuat.gov.tr/MevzuatMetin/1.5.1739.pdf

Resmi Gazete (2016a). Millî Eğitim Bakanlığı Rehberlik ve Denetim Başkanlığı ile Maarif Müfettişleri Başkanlıkları Yönetmeliğinde Değişiklik Yapılmasına Dair Yönetmelik (Sayı: 29655). Erişim adresi: https://www.resmigazete.gov.tr/eskiler/2016/03/20160316-7.htm

Sabancı, A. vd. (2016). Eğitbilime Giriş. içinde, Eğitimin Denetimi, 311-339. Editör: Erdal Toprakçı. Ankara: Ütopya Yayınevi.

Sak, U., Ayas, M.B., Sezerel, B.B., Öpengin, E., Özdemir, N.N., \& Gürbüz, D.Ş. (2015). Türkiye'de üstün yeteneklilerin eğitiminin eleştirel bir değerlendirmesi. Türk Üstün Zekâ ve Eğitim Dergisi, 5(2), 110-132.

Summak, S.M. \& Şahin, Çelik, Ç. (2014). Türkiye'de Bilim ve Sanat Merkezlerinde standartların belirlenmesi ile ilgili görüşlerin incelenmesi, Asya öğretim Dergisi, 2(1), 1-15.

Şahin, A. (1998). Bürokrasi kuramı ve Türk bürokrasisi (Yüksek Lisans Tezi, Selçuk Üniversitesi Sosyal Bilimler Enstitüsü).

Şahin, İ. (2017). Öğretmen ve müfettiş penceresinden rehberlik ve denetim çalışmalarına bakış. Kuramsal Eğitimbilim Dergisi, 10(2), 251-273. 
Taymaz, H. (2015). Teftiş ilkeler kavramlar yöntemler. Ankara. Pegem Akademi.

Teftiş Kurulu Başkanlığı (TKB). (2020). Bilim ve Sanat Merkezleri Rehberlik ve Denetim Rehberi. Erişim adresi: http://tkb.meb.gov.tr/www/yayinlarimiz/icerik/13 18 Ağustos 2020

Teftiş Kurulu Başkanlığı (TKB). (2020a). Denetim Rehberi Hazırlama Süreci. http://tkb.meb.gov.tr/meb_iys_dosyalar/2016_03/30044813_y.3.docx 18 Ağustos 2020

Teece, D. J. (2007). Explicating dynamic capabilities: the nature and microfoundations of (sustainable) enterprise performance. Strategic Management Journal, 28(13), 1319-1350.

Tonbul, Y.\&Baysülen, E. (2017) Ders denetimi ile ilgili yönetmelik değişikliğinin maarif müfettişlerinin, okul yöneticilerinin ve öğretmenlerin görüşleri açısından değerlendirilmesi, Illköğretim Online, 16(1), 299-311.

Tonbul, Y. (2020). Eğitim kurumlarında yönetimsel sorunların analizi için kuram rehberi. Ankara: Anı Yayıncilık.

Toprakçı, E.(2008). Sınıfa dayalı yönetim, Ankara: Pegem Yayınları.

Toprakçı, E., Çakırer, I., Bilbay, A., Bagcivan, E., \& Bayraktutan, I. (2010). Kuram ve uygulamada eğitim denetmenleri meslek etiği. Educational Policy Analysis and Strategic Research, 5(1), 14-23.

Toprakçı, E., \& Kadı, A. (2014). Türkiye'deki bakanlıkların eğitim yönetimi ve denetimi alanındaki faaliyetlerinin yasal belgeler eşliğinde analizi. Celal Bayar Üniversitesi Sosyal Bilimler Dergisi, 12(4), 1-18.

Toprakçı, E., \& Akçay, A. (2016). Türkiye'de kamu yararına çalışan derneklerin eğitim faaliyetlerinin yönetimi ve denetimi (yasal belgeleri temelinde nitel bir analiz). Cumhuriyet International Journal of Education, 5(1), 29.

Toprakçı, E. (2020). Denetim kuramları ve teknikleri. Prof. Dr. Erdal Toprakçı'ya ait 2019 - 2020 Bahar Yarıyılı ders notları.

Tortop, H. (2012). Olağanüstü üstün yetenekli öğrencilerin eğitim sürecinde radikal hızlandırma ve Türkiye'nin durumu. Yüksekögrretim ve bilim dergisi, 2(2), 106-113.

Tuncer, S. (1991). Değişik kaynaklardan yetişen ilköğretim müfettişlerinin rehberlik rollerinin değerlendirilmesi (Bursa Ili Örneği). Yayımlanmamış Yüksek Lisans Tezi, Uludağ Üniversitesi, Bursa.

Yazgan, E. (2020). Bilim Sanat Merkezlerinin Bolman ve Deal'ın dört çerçeve modeli açısından incelenmesi. Yayımlanmamış Yüksek Lisans Projesi, Ege Üniversitesi.

Yavuz, S.Ö. (2016). Organizasyon Kuramları. M. Polat, K. Arun, (Eds.) ,Kurumsal Kuram, Ankara: Nobel Yayıncilık

Yıldırım, A., \& Şimşek, H. (2016). Sosyal bilimlerde nitel araştırma yöntemleri (10. bs.). Ankara: Seçkin Yayıncılık.

Yücel, A. G. H., \& Toprakçı, E. (2009). Öğretmen denetiminin ihmal edilen boyutu olarak eğitsel denetim.

Weber, M. (1978). Economy and society: An outline of interpretive sociology (Vol. 1). Univ of California Press.

Weber, M. (2009). The theory of social and economic organization. Simon and Schuster. 


\section{The Investigation of Science and Arts Centers Supervisory Guideline on The Basis of Legal Documents and Literature}

\author{
Assoc. Prof. Dr. Yulmaz TONBUL \\ Ege University-Turkey \\ yilmaztonbul@gmail.com
}

\author{
Figen ATA ÇiĞDEM (Ph.D. Stud.) \\ Milli Eğitim Bakanlığı \\ atafigen@gmail.com
}

\begin{abstract}
The aim of this research is to examine the Science and Art Centers supervisory guide published by the Board of Inspectors on the basis of literature and legal documents and to determine the inconsistencies and develop suggestions for the practitioners and researchers in this direction. In the study, document review, one of the qualitative research patterns, was used, and the data were analyzed by content analysis. In the study, the rate of the inconsistency of the BILSEM supervisory guide to the legal documents found highly within the scope of the consistency theme of the BILSEM supervisory guide with legal documents. The most inconsistency with legal documents was found in the codes of the uncertainty of legal basis, lack of date according to legal documents, and overexpression according to legal basis. It is seen that the BILSEM supervision guide has a general consistency with the literature and the information produced in the science of supervision is included in the guide. However, there are deficiencies in the categories of contradictions in the supervision principles with respect to the manner in which the supervision principles are expressed, lack of references to scientific studies in some parts of the supervision guide, lack of content in the statements in the field but not in the supervision guide. The findings were interpreted and suggestions were developed, supported by related theories and the results of the field.
\end{abstract}

Keywords: Educational supervision, Supervisory guide, BILSEM, Supervisor, Inspector

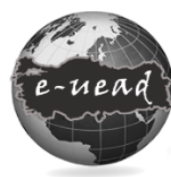

E-International Journal of Educational Research, Vol: 11, No: 3, 2020, pp.36-62

DOI: 10.19160/ijer.804118

\section{Suggested Citation:}

Tonbul, Y. \&. Ata Çiğdem, F. (2020). The Investigation of Science and Arts Centers Supervisory Guideline On The Basis of Legal Documents and Literature, E-International Journal of Educational Research, Vol: 11, No: 3, 2020, pp. 36-62, DOI: 10.19160/ijer.804118 


\section{EXTENDED ABSTRACT}

Problem: Educational supervision, actions taken in education; It is the process of examining whether it is suitable for the current legal operation, the purpose determined, the plan prepared, the substance at hand, and human resources. Supervision of the activities carried out by all institutions in the state to achieve their determined objectives is essential both for the institution itself and for the state and society. Each unchecked unit deviates from its target within itself and then begins to prevent the state mechanism from achieving its goals. For this reason, a rational auditing process is a requirement of the continuity of institutions and the state (Toprakçı etc., 2010).

In the Turkish education system, supervision as a public institution is structured for all levels of the education system, starting from course supervision to classroom supervision, school supervision, supervision of Provincial and District directorate of national education and supervision at ministerial level and these structurings show that supervision takes place at all levels The inspection guidelines for each type of school and educational institution are prepared by the Department of Inspection Board and published on its official website (Board of Inspectors, 2020). When the published supervisory guidelines are examined, it is seen that there is a supervisory guideline regarding Science and Art Centers (BILSEM).

When the literature is examined; the studies are grouped as the conditions of Science and art centers, configuration requirements (Güneş, 2018), and the impact and quality of the given education, satisfaction (Summak, Çelik \& Şahin, 2014; Koç, 2016), diagnostic processes of Student and education models (Tortop, 2012), selection of teacher and administrator to the Science and art centers (Hizlı, 2014; Keskin, Samancl ve Aydin, 2013; Kazu ve Şenol, 2012; Koç, 2016; Kılıç, 2018; Güneş, 2018; Sak., et. al, 2015; Yazgan, 2020) qualifications and opinions rights that are granted to special talented (Kazu ve Şenol, 2012). There has not been any study on the supervision of BILSEM published by the board of inspectors, nor has there been any study on the supervision guide. Although there are many studies about BILSEM institutions (Keskin, Samancl ve Aydın, 2013; Kazu ve Şenol, 2012; Koç, 2016; Güneş, 2018), no studies related to their audits have been found, institutional audits of BILSEM institutions shows that the problems related to the supervisory processes are not addressed. The research aims to examine the BILSEM supervisory guideline based on domestic literature and legal documents, to determine inconsistencies and develop suggestions for practitioners and researchers accordingly.

Method: The document analysis technique was used based on the qualitative research method. Supervisory guidelines were considered as sources suitable for document review. The study document is the BILSEM Supervision Guide from the guides published by the Department of Inspection board in 2016. In this study, a content analysis technique was used to analyze the obtained data. Content analysis was supported with quotations by the specified categories and subcodes during the data use phase. To ensure the validity of the research, confirmation of colleagues was applied. In the expert's opinion, faculties who are competent and publishing in the field of supervision and a master inspector were also included in the study. It was sent to faculties who are experts in the field of study and their opinions were included in the study. Besides, the raw data of the research has been 
stored to share it on demand or to make comparisons in other research to increase the external reliability (confirmability).

Findings: Although there are parts of the guide that are consistent with legal documents, it is concluded that there are more inconsistent articles. When the category of inconsistency is examined, it can be said that the statements regarding the outdatedness of legal documents stemmed from the constant change of legal documents and the fact that access to information is still provided by traditional methods. According to the findings regarding the legal basis uncertainty, it shows that the supervisory guidelines were not revised and comprehensively handled according to the legal documents during the preparation process. It is seen that the supervisory guideline is generally consistent with the literature based on the literature. Within the theme of inconsistency with the literature, it is one of the conclusions reached in which the code of reference to the literature stands out.

Suggestions: To reduce the inconsistency of the supervisory guideline with legal documents, a team may be appointed by the Board of Inspectors for the preparation process of the guide, and it may be recommended to include specialists in the field of educational control within the team. Within the scope of the analysis of legal documents, it can be suggested that the Ministry of National Education should include in-service training planning, data analysis training, and additions on the content of the courses such as analysis of the Turkish Education System given in universities, postgraduate education, training supervision, supervision and management, and how to prepare documents such a supervisory guideline. To maintain up-to-date according to legal documents, it is also recommended that all subdatabases be created and combined by creating a single database by developing software for the accessibility of all legal documents that the audit guide refers to. In future research, it is recommended that researchers working in the field of educational supervision develop software in cooperation with academicians who are experts in the field of informatics. To reflect the differences in institution-specific supervisory processes to the guide, it can be suggested that auditors who have experience in each institution, such as BILSEM, take part in the process of creating institution-specific guides, and in future researches, it is recommended to use opinions from different stakeholders (educational inspectors, school principals, BILSEM institution employees). 